\title{
What are our Customers Reading? An Analysis of the Most Frequently Used Subjects of the NIST Research Library Book Collection Based on Circulation
}

\section{Hassler, Harriet}

U. S. DEPARTMENT OF COMMERCE

Technology Administration

National Institute of Standards and Technology

Information Services Division

Gaithersburg, MD 20899-8230

May 2005

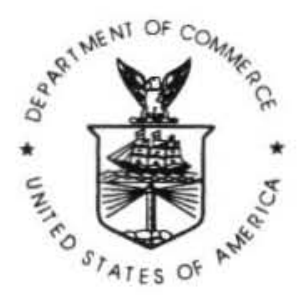

U.S. DEPARTMENT OF COMMERCE Carlos M. Gutierrez, Secretary

TECHNOLOGY ADMINISTRATION

Phillip J. Bond, Under Secretary for Technology

NATIONAL INSTITUTE OF STANDARDS

AND TECHNOLOGY

Hratch G. Semerjian, Acting Director 


\section{Table of Contents}

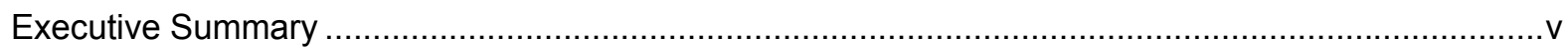

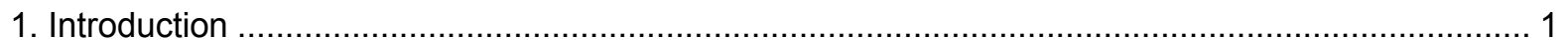

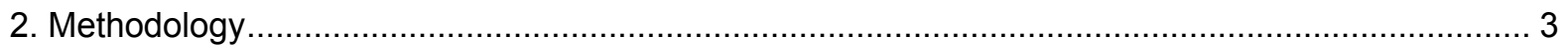

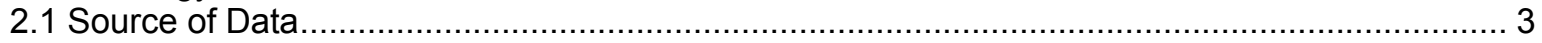

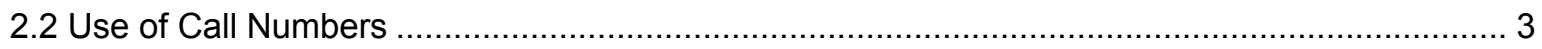

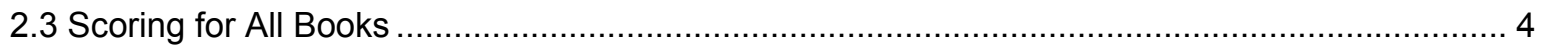

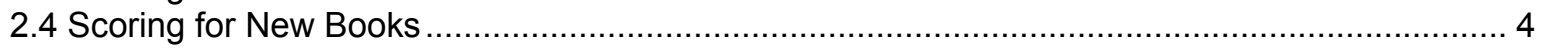

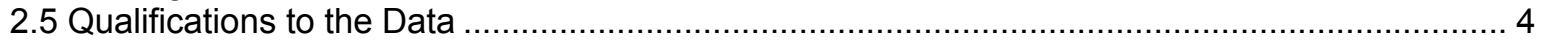

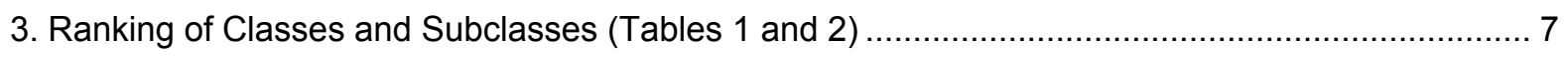

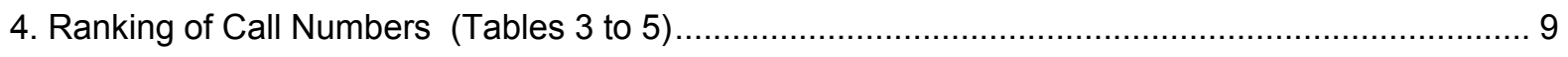

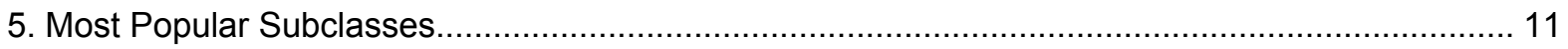

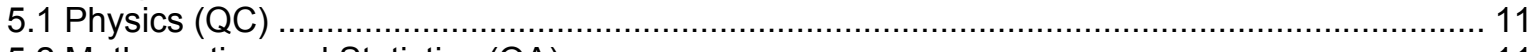

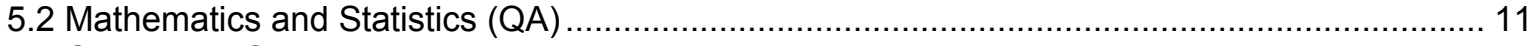

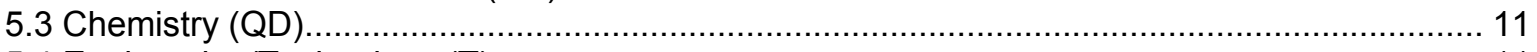

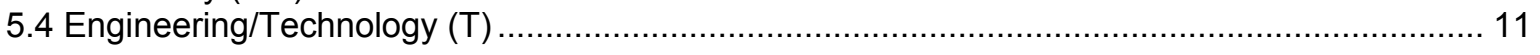

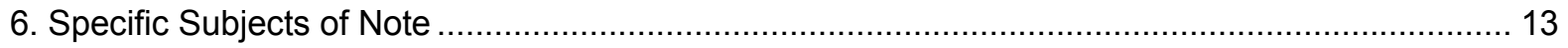

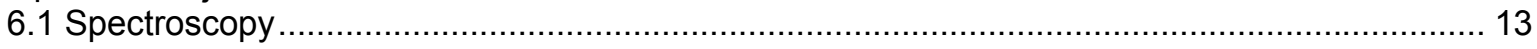

6.2 Information Technology and Computer Science .............................................................. 13

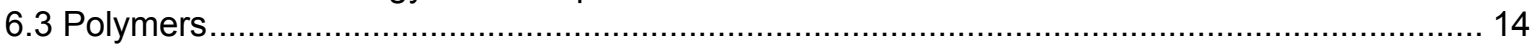

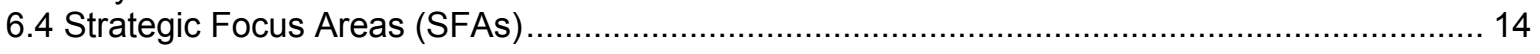

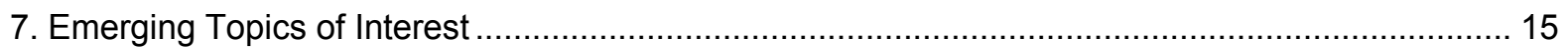

8. Analysis of Most Circulated Individual Titles (Tables 6 and 7) …........................................ 17

9. Relation to the NIST Research Library Customer Survey ................................................... 19

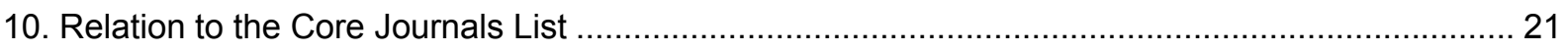

11. Recommendations for the Library Approval Plan Profile...................................................... 23

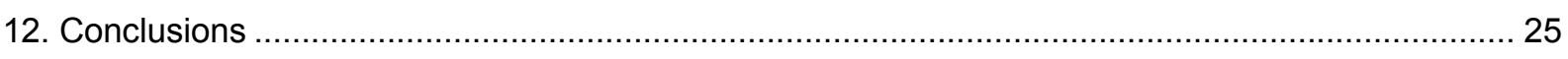

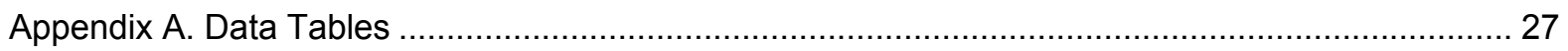

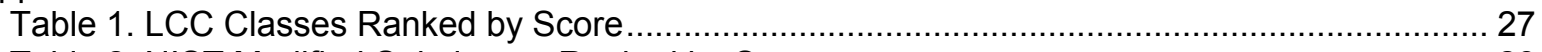

Table 2. NIST Modified Subclasses Ranked by Score ............................................................ 28

Table 3. Top 100 Call Numbers for All Books Ranked by Score …........................................... 29

Table 4. Top 50 Call Numbers for New Books (1999-2004) Ranked by Score ............................. 34

Table 5. Top Call Numbers Arranged by Call Number............................................................. 37

Table 6. Top 30 Most Circulated Titles for All Books .......................................................... 42

Table 7. Top 30 Most Circulated Titles for New Books (1999-2004) .......................................... 44 


\section{Executive Summary}

This report analyzes circulation data for the NIST Research Library book collection to determine the most used subjects. Books are grouped into subjects using their call numbers, and subjects are ranked by usage at the broad class, subclass, and specific topic level. The most circulated individual titles are also given. Tables showing rankings are given in Appendix A.

Research for this report was initiated in fiscal year 2003 as part of an Information Services Division (ISD) review of the book acquisitions processes of the NIST Research Library. The review showed that the Library received via its book approval plan almost twice as many books as it purchased. To tighten the approval plan profile to more closely match actual purchasing and reduce returns, Library staff determined to report on usage patterns in the book collection based on circulation statistics. It was hoped that the resulting report could be used to tighten the profile controlling automatic book delivery, and to serve as a general aid to the book selection process by giving Library staff one tool with which to predict the value of a purchase in terms of actual customer usage.

\section{Methodology}

Data in this study are based on a report from the Library's integrated library system (ILS) capturing all titles in the book collection that had been used since the beginning of fiscal year 2002 (October 1 , 2001) through the date the ILS report was run (February 6, 2004), a 28-month period. The report provided total circulation transactions for each title.

The subject of each book was determined using its call number. Library call numbers are created following the Library of Congress Classification (LCC) system. LCC divides the universe of knowledge into twenty-one top-level classes using alphabetic characters. Classes are broken down into subclasses, divisions, and topics using an expanded alphanumeric notation.

To create the tables for this report, titles were grouped using the LCC structure into successively more narrow categories, beginning with the top level LCC class, and working down through the subclasses to the specific call number level, denoting a specific topic.

The ILS report included 12594 titles that circulated during the period of the study. These titles, called All Books in this report, were grouped by call number into increasingly more specific categories and each category was scored according to the formula:

\section{ALL BOOKS SCORE $=($ CIRCULATION TRANSACTIONS $\times$ CIRCULATED VOLUMES $) / 1000$.}

The scoring system was devised to create a single number that gave weight to both total circulation transactions and total number of volumes circulated.

The analysis was repeated separately for the subset of books published from 1999 to 2004, called New Books in this report. There were 1157 New Books used in the period of study. New Books were scored using a similar formula:

NEW BOOKS SCORE $=($ CIRCULATED TRANSACTIONS $\times$ CIRCULATED VOLUMES $) / 100$.

The total number of available books was also recorded for each call number using the ILS reporting capabilities. This number was converted to a usage percentage using the formula:

USAGE RATE = (CIRCULATED VOLUMES / AVAILABLE VOLUMES $) \times 100$ 
Data limitations include the necessity of setting a minimum number of circulated volumes threshold for qualifying call numbers for scoring. For All Books (Table 3), the scoring threshold was 24 volumes per call number. For New Books (Table 4), the threshold was 3 volumes per call number.

\section{Ranking of Classes and Subclasses (Tables 1 and 2)}

The most used top-level classes are Science (Q), Technology (T), and Medicine (R) (Table 1). These results are expected given the focus of NIST on Science and Technology. The most popular subclasses are Physics, Mathematics, Chemistry, General Engineering, and Computer Science (Table 2).

\section{Ranking of Call Numbers (Tables 3 to 5 )}

Tables 3 and 4 show call numbers ranked by score, with subject area and specific topic, both drawn from the LCC schedules. Table 3 covers All Books. Table 4 covers New Books (1999-2004). In Table 4 , topics shown in shade are topics that did not appear in Table 3 covering All Books. These should be considered emerging topics of interest to the NIST community in the period 1999-2004 (see below).

Table 5 organizes call numbers from Tables 3 and 4 by subject. The table shows Programming, Software, Computer Systems and Special Computing, Probabilities, Statistics, Mathematical Analysis, Atomic Physics, Electricity, Analytical Chemistry, Organic Chemistry of Polymers, Physical and Theoretical Chemistry, Materials of Engineering, Telecommunication, and Electronics are the most frequently used subject areas in the book collection.

\section{Most Popular Subclasses}

At the specific call number level, in the number 1 ranked subclass, Physics, the most used topics are Spectroscopy, Solids and Solid State Physics, Particle Physics, Mathematical Physics, Semiconductor Physics, and Quantum Theory and Mechanics.

For the number 2 ranked subclass, Mathematics and Statistics, the most used topics are Mathematical Statistics, Probabilities, Nonparametric Methods, Numerical Analysis, Regression and Correlations Analysis, and Multivariate Analysis.

For the number 3 ranked subclass, Chemistry, the most used topics are Spectrum Analysis and Spectroscopy, Inorganic Elements, Polymers, Atomic and Molecular Theory and Structure, and Chromatographic Analysis.

The Technology class accounts for five of the top ten subclasses in Table 2: General Engineering, Electrical Engineering, Mechanical Engineering, Chemical Technology, and Telecommunications. The most used topics are Polymers as a Material of Engineering, Semiconductors, Microelectronics, Special Processes, Metallography, and Robotics.

\section{Specific Subjects of Note}

Several subjects deserve special mention for their notable high use. These are Spectroscopy, Information Technology and Computer Science, Polymers, and NIST Strategic Focus Area (SFA) topics.

Spectroscopy was by far the most used subject in the collection when looking at All Books (Table 3, nos. 1 and 2), and was also important when looking at New Books (Table 4, nos. 9 and 23). Spectroscopy is a highly used subject area both in the discipline of Chemistry and in the discipline of Physics. 
Information Technology and Computer Science account for multiple entries on the tables for All Books (Table 3), New Books (Table 4), and most circulated individual titles (Tables 6 and 7). Among the most popular topics are Operating Systems, Java, Hypertext Systems, Software Topics, Computer Topics, Database Management, Computer-aided Engineering, Programming Languages, Computer Graphics, Object-oriented Computing, C Programming Languages, Quantum Computing, Client/Server Computing, Database Design, and Visual Basic. Telecommunications also accounted for several popular topics including World Wide Web, Signal Processing, TCP/IP, and Active Server Pages.

Polymers accounted for four out of seventeen top Chemistry call numbers (see Table 5, QD), and also occurred as popular topics in the disciplines of Physics, Medicine, Materials Science, and Chemical Engineering. This fits with the fact that during the period of study the Polymers Division within the Materials Science and Engineering Laboratory (MSEL) was the division with the highest circulation level among all divisions at NIST.

NIST SFAs of Nanotechnology, and Healthcare/Biotechnology are readily apparent in the lists of high use topics. From Table 5, they are specifically addressed by the topics Biomedical Engineering, Biomedical Materials, Nanotechnology, Nanostructure Materials, Microelectronics, and Microelectromechanical Systems. Other popular topics with applications in SFA research include Surfaces, Quantum Mechanics, Solid State Physics, Spectroscopy, Semiconductors, Polymers, Scanning Microscopes, Biochemistry, Robotics, and Control Engineering.

\section{Emerging Topics of Interest}

Topics that rank among the most popular for New Books (Table 4) but which are not on the list for All Books (Table 3) are considered emerging topics of interest. These emerging topics are Nanostructure Materials, Nanotechnology, Bayesian Statistics, Signal Processing, Microelectromechanical Systems (MEMS), TCP/IP, Active Server Pages, Biomedical Materials, Object-Oriented Computing, Quantum Computing, Client/Server Computing, Carbon as a Material in Engineering, Special Topics in Research, Special Types of Polymers, Database Design, and Visual Basic Programming. Almost all relate directly to the NIST SFAs of Nanotechnology, Biotechnology, and Information/Knowledge Management.

\section{Analysis of Most Circulated Individual Titles (Tables 6 and 7)}

Table 6, Top 30 Most Circulated Titles for All Books, shows individual titles with the greatest number of total circulation transactions (in-house uses and checkouts combined). Books with subjects shown in bold are on topics whose popularity is predicted by appearance on Table 5. Programming, in particular $\mathrm{C} / \mathrm{C}++$, accounts for the largest number of most circulated books. Many of the most circulated popular books are textbooks, including many older classics.

Table 7, Top 30 Most Circulated Titles for New Books (1999-2004), shows individual books published in 1999 or later with the greatest number of total circulation transactions (in-house uses and checkouts combined). Books with subjects shown in bold are on topics whose popularity is predicted by appearance on Table 5. Again, Programming is the most represented area, including Visual Basic, Java, and Object-Oriented.

\section{Relation to the NIST Research Library Customer Survey}

The NIST Research Library customer survey conducted in 2001 supports the findings of this report that the book collection is valued and used. High use subjects in the customer survey were Physics, Engineering, Chemistry, Computers/Information Technology, Materials Science, and Mathematics. These are consistent with high use subjects identified in this report. High use types of resources in the customer survey included conference proceedings, textbooks, and technical books, all of which are generally part of the book collection and procured with the Library's book budget. However, 
satisfaction with technical books, textbooks and conference proceedings was relatively low. The survey report stated that these collections should be improved.

In the customer survey, textbooks scored in the "very high use" category. This agrees with the findings of this report that show textbooks are the most circulated items in the Library. The Library should purchase textbooks that are rated favorably by Subject Specialists and which support NIST research. The Library should also be proactive in checking for the availability of new editions of textbooks that have proved popular in the past.

\section{Relation to the Core Journals List}

In 2002, the NIST Research Library developed a core journals list with input from each of the divisions in the NIST Laboratories. The core journals list is categorized by subjects most similar to those shown on Table 2, NIST Modified Subclasses Ranked by Score. Based on number of titles per category, core journals rank by subject as follows, from highest to lowest: Engineering, Physics, Chemistry, Materials Science, and Computer Science. As shown in Table 2, subclasses rank by circulation as follows, from highest to lowest: Physics, Mathematics, Chemistry, General Engineering, and Computer Science.

The two lists roughly correlate but show some differences. Some of these differences are attributable to different methods of categorization in the two lists. For instance, in this report Materials Science was not a separate category but fell under General Engineering. Mathematics stands out strongly as a high use category in this study, but only ranked sixth on the core journals list. Clearly, users turn to the Library book collection for information on Mathematics a great deal, but few divisions considered Mathematics as a "core" research area when it came to the journal collection.

\section{Recommendations for the Library Approval Plan Profile}

The Library's approval plan profile controls by topic which books are sent to the Library for review automatically. The automatic delivery of books on the approval plan is an important part of the acquisition process. Through this method, books that are most pertinent to the research needs of the organization arrive without any proactive effort required by Library staff or Subject Specialists. However, in order for the approval plan to work as intended, the Library must have a book budget that roughly corresponds to the number of books that are sent on approval. When the Library's book acquisitions drop below 500 titles per year, the approval plan becomes difficult to operate. For fiscal years 2004 and 2005, automatic delivery has been temporarily suspended due to budget constraints.

In general, the NIST book approval plan profile is well tailored to the needs of the organization. When activated, automatic book delivery is currently concentrated in Physics, Chemistry, General Engineering, Mechanical Engineering, and Telecommunications. However, following the findings of this report, the profile should be refined by adding more coverage for popular areas in Mathematics and Computer Science, Biochemistry, and Biomedical Engineering. Book shipment should be reduced in the lesser-used areas of Physics, Chemistry, Technology and Engineering; the Library would continue to be notified of newly published works in these areas by receiving a slip describing the book in place of the physical volume.

\section{Conclusions}

Through the customer survey and through circulation patterns shown in this report, Library customers have stated that the book collection is an important and highly used resource. This report provides an outline of subject areas in which collection development will almost certainly result in resources that are highly used and generate substantial return on investment (ROI). These subjects include but are not limited to NIST SFAs. They also include many subjects of broad interest to the research community, such as spectroscopy, and of practical utility to bench scientists, such as computer programming. 
The results of this report suggest that NIST staff use the book collection to learn about topics that support their research, such as programming, research methodology, and statistical analysis, as much if not more than to learn about their specific areas of expertise. Studies of information use by scientists have shown that journals, not books, are the single most important information resource for maintaining current awareness in the fields of science and engineering. At NIST, this study suggests that the book collection is more likely to be used to investigate fields in which the scientist is less familiar, but in which a situational need for more knowledge has occurred. Among the most popular books in the collection are a number of classic textbooks, supporting the thesis that the Library should view the book collection not only as a resource for subject experts, but also for non-experts coming in from outside a discipline to get an introduction to a new topic.

In recent fiscal years, budget cuts to the Library have made collection development challenging. As the Library continues to operate with a limited book budget, it is paramount that titles purchased are effective and utilized. The Library can aim to achieve high usage of new acquisitions by close monitoring of circulation of existing resources by its customers. This study represents one attempt to do such monitoring.

This report illuminates popular subject areas. High usage rates in many of these subjects, especially for new books, shows that the Library's acquisition program has been successful. The Library has identified what its customers are reading and knows what it should be buying. The Library is ready to make sound purchasing decisions and to measure its performance. The Library book collection should continue to be funded to maintain and improve its current level of success and customer satisfaction. 


\section{Introduction}

This report analyzes circulation data for the NIST Research Library Book Collection in fiscal years 2002, 2003, and part of 2004 to determine the most used subjects in the collection. Books are grouped into subjects using their call numbers (see section 2.2 for further discussion), and ranked by usage. In Appendix A, rankings are given by broad class and subclass (Tables 1 and 2), and by specific topic (Tables 3-5). Table 3 covers all books that circulated within the period of study. Table 4 covers only those books published between 1999 and 2004 that circulated within the period of study. Table 5 shows the top call numbers arranged by subject rather than ranking. The most circulated individual titles are also given (Tables 6 and 7 ).

This report was initiated in fiscal year 2003 when the Information Services Division (ISD), which includes the NIST Research Library, tasked two librarians to review the book acquisitions processes. This review included an assessment of the book approval plan with the Library's current book vendor. According to the Library's profile with the vendor, books in certain subjects are sent automatically without being specifically ordered. The review showed that the Library only purchased about half of these books. In addition, of all books purchased, only $15 \%$ were originating from the automatic book shipments. The high rate of return placed cost and time burdens on the Library's staff, as well as on the vendor's. In looking for ways to tighten the profile to more closely match actual purchasing, an assessment of Library customers' usage became an area of interest for investigation. Library staff therefore determined to report on usage patterns in the book collection based on circulation statistics. It was hoped that the resulting report could be used to tighten the profile with the vendor to include only those topics of very high interest to Library customers. It was also hoped that the resulting report could serve as a general aid to the book selection process by giving Library staff one tool with which to predict the value of a potential purchase in terms of actual customer usage. 


\section{Methodology}

\subsection{Source of Data}

This study is based on a report from the circulation module of the Library's integrated library system (ILS) produced on February 6, 2004. The report captured all titles that had been used since the beginning of fiscal year 2002 (October 1, 2001) through the date the ILS report was run (February 6 , 2004), a 28-month period. The report looked only at the book collection and excluded circulation of titles in the journal collection. For each title, the report included call number, date last used, number of in-house uses, number of checkouts, and total number of circulation transactions (in-house uses and checkouts combined). An in-house use is counted when a book is taken from the shelf by a customer and left in the Library; it is recorded in the ILS by Library staff before the item is reshelved. Although a book had to have been used within the 28-month period to appear on the report, the number of in-house uses and checkouts included all activity going back to the implementation of the automated circulation system in August 1991. The ILS does not support reporting on use for an individual item within a specified time period. Therefore, throughout this report, the reader should keep in mind that every book included had circulated at least once during fiscal years 2002-2004; however, total circulation transactions were calculated over the period 1991 to February 2004.

\subsection{Use of Call Numbers}

A call number is a mark of notation used to arrange books by subject. The first part of a call number is the class notation, which identifies the subject of the book. The second part is the book number, which uniquely identifies an item and is used to arrange books within a topic in a meaningful way, usually by author. For the purposes of this study, the term "call number" refers to the class notation only. The NIST Research Library uses Library of Congress Classification (LCC) to create call numbers. LCC divides the universe of knowledge into twenty-one top-level classes using alphabetic characters. Classes are broken down into subclasses and divisions using an expanded alphanumeric notation.

For example, the top ranking call number on Table 3 is QD96, which represents:

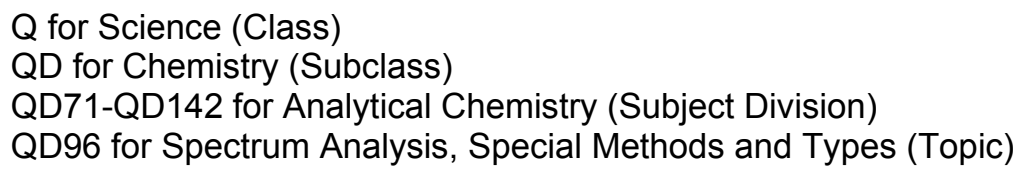

Some topics are further subdivided into more specific subtopics using a "Cutter" number (named after the system of subdivision's creator, Charles A. Cutter), which is a second letter-number string following the base class number. For example, the top ranking call number on Table 4 is QA76.76 .063, which uses the Cutter number .063 and represents:

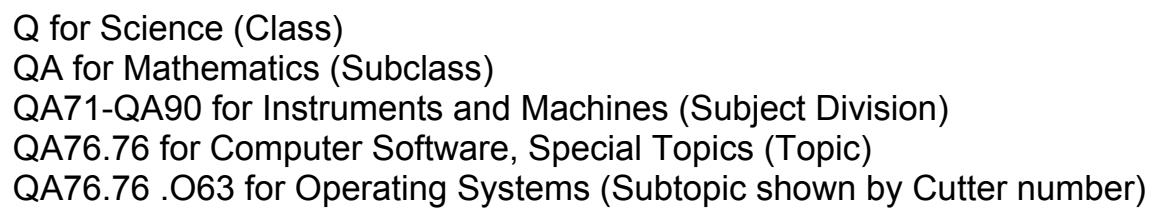

To create the tables for this report, titles were grouped using the LCC structure into successively more narrow categories, beginning with the top level LCC class, and working down through the subclasses to the specific call number level. 


\subsection{Scoring for All Books}

The ILS report included 12594 books that circulated during the period of the study. There were 216083 circulation transactions for these materials (in-house uses and checkouts). These titles, called All Books in this report, were grouped by call number into increasingly more specific categories and each category was scored. The score was calculated by multiplying the total circulation transactions by the number of circulated volumes, then dividing by 1000 :

SCORE $=($ CIRCULATION TRANSACTIONS $\times$ CIRCULATED VOLUMES $) / 1000$.

The scoring system was devised to create a single number that gave weight to both total circulation transactions and total number of volumes circulated. Thus, given two call numbers with equal numbers of transactions, the call number that had more circulated volumes would outscore the other.

Where call numbers used Cutter numbers to denote subtopics, if the Cutter number qualified for scoring independently, the subtopic was scored separately. If the call number had Cutter numbers but none qualified for scoring independently, then the call number was scored as a whole without regard to Cutter numbers. As discussed in section 2.5, to qualify for scoring, a call number had to have 24 or more titles circulated for All Books, or 3 or more titles circulated for New Books.

The total number of available books was also recorded for each call number using the ILS reporting capabilities. This number was converted to a usage percentage using the formula:

USAGE RATE $=($ CIRCULATED VOLUMES / AVAILABLE VOLUMES $) \times 100$

\subsection{Scoring for New Books}

The analysis was repeated separately for the subset of books published from 1999 to 2004, called New Books in this report. Since these books could not have been used prior to 1999, this analysis was intended to isolate the most current and emerging interests of Library customers. Again categories were scored. The formula was the same as for All Books, except that, because numbers were smaller (there were roughly 10 times fewer books), the product of total circulation transactions and total circulated volumes was divided by 100 rather than by 1000 :

SCORE $=($ CIRCULATION TRANSACTIONS x CIRCULATED VOLUMES $) / 100$.

There were 1157 New Books published in 1999 or later used in the 28-month period of study, with 13306 total circulation transactions. According to the ILS, there were approximately 2000 books published in 1999 or later available for circulation when the usage data was collected. This suggests that many new books did not circulate, however, due to data limitations, only limited conclusions should be drawn from this. Not all new books were purchased; some were gifts. Also, the length of time each new book had been available varied; some had only been available for checkout a short period. A valid measure of usage of purchased new books requires a separate analysis using more targeted data.

\subsection{Qualifications to the Data}

Call numbers were only considered for inclusion in the Top 100 Call Numbers for All Books list (Table 3 ) if 24 or more individual titles in that call number had circulated in the period of study. It was beyond the time resources available for this report to score every call number; therefore, a threshold had to be set. Because of the threshold, the analysis may favor those call numbers in which the collection was already strong. A call number of high interest in which the Library had not collected adequately may not have made it into the report because it did not meet the threshold of 24 items. The threshold for the Top 50 Call Numbers for New Books list (Table 4) was much more easily attainable at 3 items. Table 5, in which Top Call Numbers are arranged by subject, is intended to 
reduce bias by looking beyond individual call numbers to broader subject ranges illuminating wider areas of high interest to customers.

The ILS report provided total circulation transactions per volume but the system is unable to provide total number of users per volume. Therefore, this report could not take into account the fact that some titles attain a high number of transactions by being renewed multiple times by a singer user. For this report, each renewal counted as one transaction.

To maintain the privacy of library users, the ILS does not keep a history of the activity of individual users. No records pertaining to any individual users were obtained or analyzed for this report. 


\section{Ranking of Classes and Subclasses (Tables 1 and 2)}

Table 1, LCC Classes Ranked by Score, shows that the Q class representing Science is by far the most popular class, followed by the T class, representing Technology. The class R, for Medicine, is a distant third. These results are expected given the focus of NIST on Science and Technology.

For Table 2, NIST Modified Subclasses Ranked by Score, LCC classes were broken down into smaller subclasses, scored and ranked. Subclasses on Table 2 are modified from LCC in some cases based on local interests and usage. For instance, the subclasses Physics and Chemistry match the top-level breakdown of the LCC Q schedule: QC for Physics, QD for Chemistry. However, the subclass QA, titled Mathematics in LCC, was broken down into two parts, Mathematics and Computer Science, for this report since Computer Science traditionally has been treated as a separate subject area by the NIST Research Library.

The results show the top five most popular subclasses are Physics, Mathematics, Chemistry, General Engineering, and Computer Science. In Medicine, the most popular subclass is Bioengineering. In Social Sciences, the most popular subclass is Management.

The high use of Physics, Chemistry, and Engineering is expected since these subjects clearly correspond to research specialties of the NIST Laboratories. Less expected is the high use of Computer Science and Information Technology related books, including books on programming languages and software. These are not only high use subjects, but account for many of the most popular individual titles as well. These results are less expected because the Information Technology Laboratory (ITL) ranks only fourth among Laboratories for use the book collection. ${ }^{1}$ However, Computer Science and Information Technology are intrinsically part of all types of scientific research today. This accounts for the high usage of books on these subjects.

Mathematics is a surprisingly highly used subclass because, unlike Physics or Chemistry, Mathematics is not a core research area associated with a particular NIST Laboratory, although ITL includes divisions for Mathematical and Computational Sciences and for Statistical Engineering. Factors contributing to the high usage of Mathematics include its relevancy and applicability to all types of research. Also, studies have shown that mathematicians use monographs and cite older materials more than scientists in other disciplines, which points to greater utilization of the book collection in the area of Mathematics. ${ }^{2}$

\footnotetext{
${ }^{1}$ For fiscal year 2003, from data collected by NIST Research Library integrated library system, book circulation by NIST Laboratory ranked as follows based on number of checkouts: 1. MSEL (28\%), 2. PL (20\%), 3. CSTL (16\%), 4. ITL (11\%), 5. MEL (9\%), 6. BFRL (7\%), 7. EEEL (4\%), 8. TS (1\%),

2 Cecelia M. Brown, Information seeking behavior of scientists in the electronic information age: astronomers, chemists, mathematicians, and physicists, J. Am. Soc. Inf. Sci. 50 (10), 929-943 (1999).
} 


\section{Ranking of Call Numbers (Tables 3 to 5)}

To produce Table 3, Top 100 Call Numbers for All Books Ranked by Score, books from the circulation report were grouped by call number. Call numbers that had more than 24 individual volumes represented were selected for scoring. Call numbers are shown ranked by score, with subject area and specific topic, both drawn from the LCC schedules.

Table 4, Top 50 Call Numbers for New Books (1999-2004) Ranked by Score, only considered books that had been published in 1999 or later. For Table 4, a call number only had to have 3 or more titles in order to qualify for scoring. In Table 4, topics shown in shade are topics that did not appear in Table 3 covering All Books. These should be considered emerging topics of interest to the NIST community in the period 1999-2004 (see section 7).

Many subjects on Table 4 also showed very high usage rates, approaching or reaching $100 \%$. Where this is true, it indicates that almost every book the Library owned on that subject was used.

Table 5, Top Call Numbers Arranged by Call Number, organizes call numbers from Tables 3 and 4 by subject. Table 5 is intended to place high use call numbers within a broader context to reveal what subject areas are of greatest interest to customers. The table shows Programming, Software, Computer Systems and Special Computing, Probabilities, Statistics, Mathematical Analysis, Atomic Physics, Electricity, Analytical Chemistry, Organic Chemistry of Polymers, Physical and Theoretical Chemistry, Materials of Engineering, Telecommunication, and Electronics are among the most frequently used subject areas in the book collection. 


\section{Most Popular Subclasses}

\subsection{Physics (QC)}

The call number subclass for Physics, QC, is the most used subclass in the book collection. Major subject areas of interest are Atomic Physics, Optics, and Electricity. From Table 3, Top Physics topics include (in rank number order):

Spectroscopy / QC454 (no. 2)

Solids and Solid State Physics / QC176, QC176.8 (nos. 4 and 17)

Particle Physics / QC793.5 (no. 8)

Mathematical Physics / QC20.7 (no. 18)

Semiconductor Physics / QC611.6 (no. 19)

Quantum Theory and Mechanics / QC174.12 (no. 21)

\subsection{Mathematics and Statistics (QA)}

Books in the QA class, covering Mathematics, show very high usage. Mathematics has higher circulation numbers than Chemistry, even excluding computer science books, which are also in QA, from the Mathematics category. From Table 3, Top Mathematics and Statistics topics include (in rank number order):

Mathematical Statistics, General / QA276 (no. 6)

Probabilities, General / QA273 (no. 7)

Nonparametric Methods / QA279 (no. 24)

Numerical Analysis / QA297 (no. 25)

Regression and Correlations Analysis / QA278.2 (no. 27)

Multivariate Analysis / QA278 (no. 30)

\subsection{Chemistry (QD)}

The subclass QD for Chemistry is the third most used subclass after Physics and Mathematics. Major subject areas of interest are Analytical Chemistry, Organic Chemistry, and Physical and Theoretical Chemistry. From Table 3, Top Chemistry topics include (in rank number order):

Spectrum Analysis, Spectroscopy QD96 (no. 1)

Inorganic Elements / QD181 (no. 10)

Polymers / QD381, QD381.9 (nos. 12 and 40)

Atomic and Molecular Theory and Structure / QD461 (no. 16)

Chromatographic Analysis / QD79.C4-.C8 (no. 31)

\subsection{Engineering/Technology (T)}

The class T accounts for five of the top ten subclasses in Table 2: General Engineering (TA), Electrical Engineering (TK pt.1), Mechanical Engineering (TJ), Chemical Technology (TP), and Telecommunications (TK pt. 2). Major subject areas of interest are Materials of Engineering, Engineering Mathematics, Robotics, and Electronics. From Table 3, top Technology and Engineering topics include (in rank number order):

Polymers as a Material of Engineering / TA455 .P58 (no. 9)

Semiconductors / TK7871.85 (no. 11)

Microelectronics / TK7874 (no. 22)

Special Processes / TP156 (no. 23)

Metallography / TN690 (no. 33)

Robotics / TJ211 (no. 34) 


\section{Specific Subjects of Note}

\subsection{Spectroscopy}

Spectroscopy was by far the most used subject in the collection when looking at All Books (Table 3). It was also important when looking at New Books (Table 4). The number 1 and number 2 ranked call numbers for All Books both dealt with spectroscopy. The call number QD96, in the subject area Analytical Chemistry, covers special types of spectroscopy including infrared, mass, and nuclear magnetic resonance. The call number QC454, in the area of Optics, covers different types of spectroscopy such as electron, laser, and molecular. Spectroscopy is a highly used subject area both from a Chemistry perspective and from a Physics perspective.

\subsection{Information Technology and Computer Science}

Information Technology and Computer Science account for the most used subjects in the collection when looking at New Books (Table 4). They are also very important when looking at All Books (Table 3). Two of the top five call numbers for All Books and four of the top five call numbers for New Books cover information technology and computer-related topics. These types of topics appear frequently throughout Tables 6 and 7, listing most circulated individual titles. C programming language books in particular are high-circulating items. From Table 4, the most popular call numbers include (in rank number order):

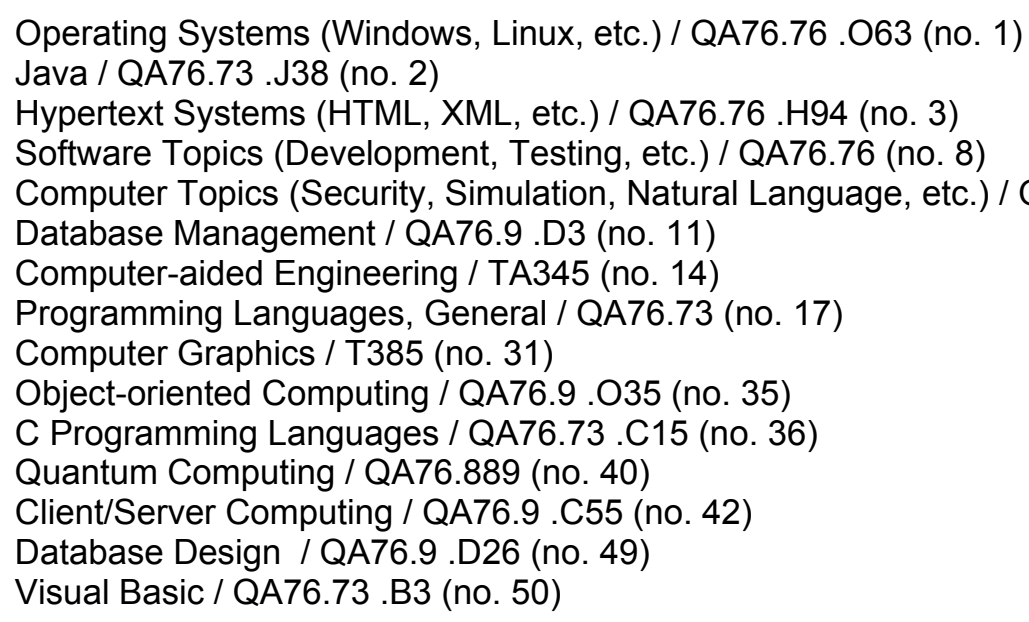

The field of Telecommunications also includes a number of popular IT-related call numbers including (in Table 4 rank number order):

World Wide Web / TK5105.888 (no. 4)

Signal Processing / TK5203.59 (no. 16)

TCP/IP / TK5105.585 (no. 29)

Active Server Pages / TK5105.8885 .A26 (no.30) 


\subsection{Polymers}

Several high use call numbers deal with the subject of Polymers. This fits with the fact that during the period of study the Polymers Division within the Materials Science and Engineering Laboratory (MSEL) was the division with the highest circulation level among all divisions at NIST. ${ }^{3}$ Polymers as a topic are covered within several different disciplines, including Chemistry, Physics, Medicine, and Engineering. Most prominently in the class Chemistry (QD), Polymers account for 4 of the 17 top call numbers shown in Table 5, including (in call number order):

\section{Polymerization and Telomerization / QD281 .P6}

Polymers, General / QD381

Special Topics (electric properties, solubility, surfaces, rheology, etc.) / QD381.9

Special Types of Polymers (conductors, crystalline, water-soluble, etc.) / QD382

Outside Chemistry, Polymers also occur as a facet in other disciplines. Polymers are included as subtopics in the following call numbers from Table 5 (in call number order):

Atomic Physics - Matter and Antimatter / QC173.4

Biomedical Engineering / R857

Materials of Engineering / TA455 .P58

Chemical Engineering / TP156)

\subsection{Strategic Focus Areas (SFAs)}

NIST SFAs of Nanotechnology, and Healthcare/Biotechnology are readily apparent in the lists of high use topics. From Table 5, they are specifically addressed by the following topics (in call number order):

Biomedical Engineering (R857)

Biomedical Materials (R857 .M3)

Nanotechnology (T174.7)

Nanostructure Materials (TA418.9 .N35)

Microelectronics (TK7874)

Microelectromechanical Systems (TK7875)

Other popular topics with applications in SFA research include (from Table 5, in call number order):

Surfaces (QC173.4 .S94)

Quantum Mechanics (QC174.12, QC174.17)

Solid State Physics (QC176, QC 176.8)

Spectroscopy (QC454, QD96)

Semiconductors (QC611, QC611.6, QC612 .S4, TK7871.85)

Polymers (QD281 .P6, QD381, QD381.9, QD382)

Scanning Microscopes (QH212 .S3x)

Biochemistry (QP519.9)

Robotics (TJ211)

Control Engineering (TJ213)

\footnotetext{
${ }^{3}$ Based circulation data collected from the NIST Research Library ILS covering fiscal year 2003.
} 


\section{Emerging Topics of Interest}

Topics that rank among the most popular for New Books (Table 4) but which are not on the list for All Books (Table 3 ) are considered emerging topics of interest. These emerging topics, shown in shade on Table 4, include (in rank number order):

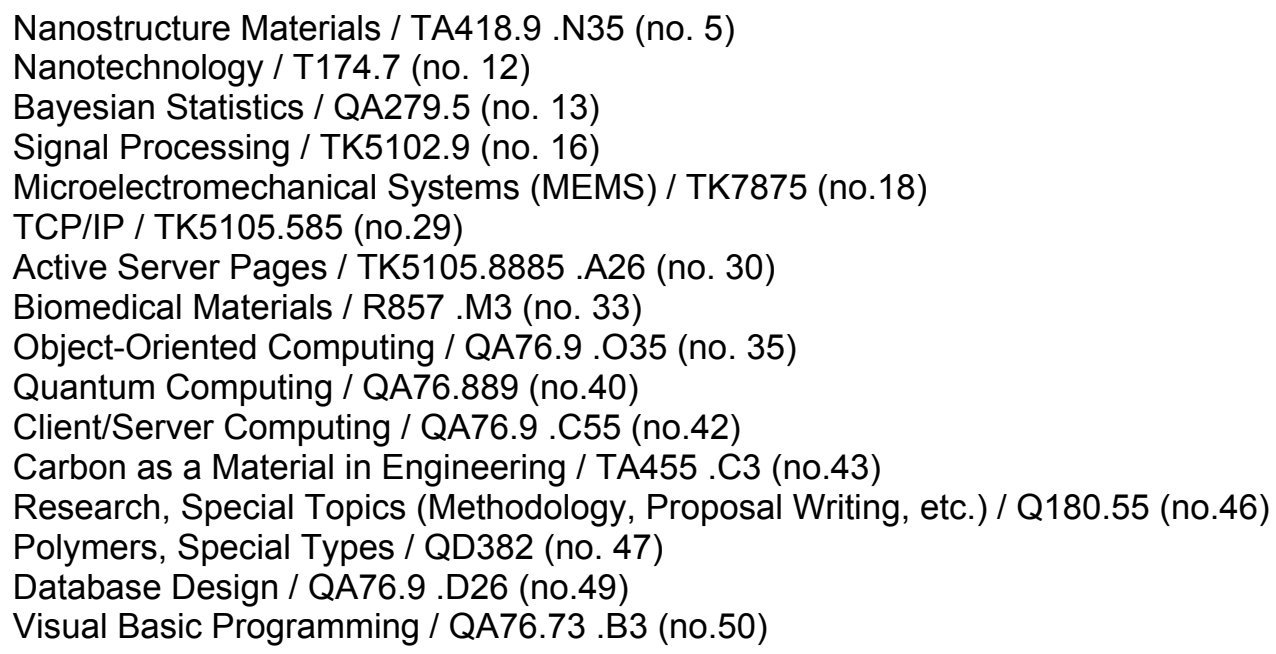

Almost all relate directly to the NIST SFAs of Nanotechnology, Biotechnology, and Information/Knowledge Management. 


\section{Analysis of Most Circulated Individual Titles (Tables 6 and 7)}

Table 6, Top 30 Most Circulated Titles for All Books, shows individual books with the greatest number of total circulation transactions. Total transactions were counted from August 1991 onward, however every book circulated at least once between October 2001 and January 2004. Books with subjects shown in bold are on topics whose popularity is predicted by appearance on Table 5 . Twenty-seven of thirty books are in subject areas appearing on Table 5. Twelve of thirty are on specific topics appearing on Table 5. Programming, in particular $\mathrm{C} / \mathrm{C}++$, accounts for the largest number of most circulated books.

Even though all usage that was counted to produce Table 6 occurred from 1991 onwards, many of the books were published substantially before 1991. Many older books continue to circulate regularly. These are mostly textbooks. Among the titles that could be considered "classic" textbooks are Draper and Smith's Applied Regression Analysis (Table 6, no. 2), Press's Numerical Recipes: the Art of Scientific Computing (Table 6, no. 5), and Westcott's pH Measurements (Table 6, no. 16). Each of these is currently owned by over 800 libraries in the U.S. according to the WorldCat database maintained by the Online Computer Library Center (OCLC).

Table 7, Top 30 Most Circulated Titles for New Books (1999-2004), shows individual books published in 1999 or later with the greatest number of total circulation transactions. Books with subjects shown in bold are on topics whose popularity is predicted by appearance on Table 5. Twenty-eight of thirty books are in subjects appearing on Table 5. Fourteen of thirty are on specific topics appearing on Table 5. Programming is the most represented area, including Visual Basic, Java, and ObjectOriented. 


\section{Relation to the NIST Research Library Customer Survey}

The fact that 12594 individual titles circulated within the 28-month period of study proves that the book collection is a valuable resource in which NIST should continue to invest. The NIST Research Library customer survey conducted in 2001 also supports this conclusion. High use subjects reported in the survey were Physics, Engineering, Chemistry, Computers/Information Technology, Materials Science, and Mathematics. These are consistent with high use subjects identified in this report. High use types of resources in the survey included conference proceedings, textbooks, and technical books, all of which are generally part of the book collection and procured with the Library's book budget. These were also reported to be of great value by $50 \%$ or more of respondents. However, satisfaction with technical books, textbooks and conference proceedings was relatively low. There were several comments about the importance of these collections, and about the need for more and newer textbooks. The survey report stated that these collections should be improved. ${ }^{4}$ Customers liked the quality and scope of the Library collection, but felt there were not enough resources.

In the customer survey, textbooks scored in the "very high use" category. This agrees with the findings of this report that shows textbooks are the most circulated items in the Library. The Library of Congress has defined textbook as "a work that presents a particular subject in an organized and simplified manner and is explicitly intended to be used for the purpose of learning that subject." ${ }^{5}$ The Library should purchase textbooks that are rated favorably by Subject Specialists and which support NIST research. The Library should also be proactive in checking for the availability of new editions of textbooks that have proved popular in the past.

\footnotetext{
${ }^{4}$ E.G. Abels and D.L. Barlow, NIST OIS Customer Survey Report, NIST Office of Information Services, 2002, sect. 6.3.2.

5 Library of Congress, Subject Cataloging Manual: Subject Headings, The Library, Washington, D.C. (2002) p.H2187.
} 


\section{Relation to the Core Journals List}

In 2002, the NIST Research Library developed a core journals list with input from each of the divisions in the NIST Laboratories. This core journals list is categorized by subject. To compare to this report, the core journal list subjects are most similar to those shown on Table 2, NIST Modified Subclasses Ranked by Score. Based on number of titles per category, core journals rank by subject as follows:

1. Engineering (190 of 650 titles)

2. Physics (175 of 650$)$

3. Chemistry (111 of 650$)$

4. Materials Science (87 of 650$)$

5. Computer Science ( 85 of 650 )

As shown in Table 2, subclasses rank by circulation as follows:
1. Physics
2. Mathematics
3. Chemistry
4. General Engineering
5. Computer Science

In relation to one another, the two lists roughly correlate but show some differences. Some of these differences are attributable to different methods of categorization in the two lists. Table 2 of this study used modified LCC subclasses to categorize materials. This method divided Engineering into a number of smaller categories: General Engineering, Electrical Engineering, and Mechanical Engineering. The core journals list took all of these together, so it is not surprising that the Core Journals category Engineering would rank higher on that list since it was more inclusive than the LCC General Engineering category.

Another difference is with Materials Science, which appears on the core journals list but not on the list from Table 2. This can also be attributed to the structure of LCC, which does not have a separate breakout subclass for Materials Science. Instead, Materials Science in LCC falls within the General Engineering category.

One difference not attributable to different categorization schemas concerns Mathematics. Mathematics stands out strongly as a high use category in this study, but only ranked sixth on the core journals list. Clearly, users turn to the Library book collection for information on Mathematics a great deal, but it is likely that scientists other than mathematicians do this to support research in other areas, rather than as a subject of research itself. Therefore, it is not surprising that few divisions considered Mathematics as a "core" research area when it came to the journal collection. 


\section{Recommendations for the Library Approval Plan Profile}

The NIST Research Library currently uses a book approval plan service. Like most plans, the NIST plan features two types of notification of newly published works: slip and book. For slip notification, the Library receives a brief bibliographic description of the book. Approximately 30 Subject Specialists from the NIST Laboratories review the slips and suggest books to order. For book notification, the Library receives the actual book automatically, on an "approval" basis, which means it can be returned if the Library chooses. The Library's approval plan profile controls which topics are received as slips and which topics are received as books. The profile is structured according to LCC. Once the books are reviewed by Subject Specialists, librarians decide which titles to purchase, taking into account their knowledge of the NIST Laboratories and input from NIST Strategic Working Groups.

The automatic delivery of books on the approval plan is an important part of the acquisition process. Through this method, books that are most pertinent to the research needs of the organization arrive without any proactive effort required by Library staff or Subject Specialists. However, in order for the approval plan to work as intended, the Library must have a book budget that roughly corresponds to the number of books that are sent on approval. When the Library's book acquisitions drop below 500 titles per year, the approval plan becomes difficult to operate. If the budget is too small it becomes a pointless exercise to receive books automatically only to return the great majority. In fiscal year 2004, the Library temporarily suspended automatic delivery due to budget constraints that limited purchases to approximately 350 titles. This suspension has continued into fiscal year 2005 due to lack of funds.

In general, the NIST book approval plan profile is well tailored to the needs of the organization. When activated, book notification is currently concentrated in Physics, Chemistry, General Engineering, Mechanical Engineering, and Telecommunications. This report suggests the need for the following changes to the profile. When book notification is cancelled for a subject, coverage would continue as slip notification.

QA: Mathematics and Computer Science. The Library's profile is set to receive slip notification only across the board. The Library should add book notification coverage for Programming, Software, Computing, Mathematical Statistics, and Mathematical Analysis to cover the call numbers listed on the report.

QC: Physics. The profile is set to receive book notification for almost the entire subclass. This analysis indicates that the Library should scale back book coverage to only cover the specific tight ranges on the report, and convert other ranges to slip notification coverage. Specifically, exclude book coverage for QC200s, covering Acoustics and Sound, and QC500s, covering Instruments and Apparatus of Electricity. Both ranges had no top call numbers.

QD: Chemistry. The profile is set to receive book notification for the entire subclass. The Library should scale back book coverage to only cover the specific tight ranges on the report, and convert other ranges to slip coverage. Due to lack of high circulation, the Library should specifically exclude book coverage for QD600-QD899, covering Radiation Chemistry and Photochemistry.

QP: Biochemistry. Add book notification coverage for QP519.9, Biochemistry Technique. Coverage is slip notification only.

R: Medicine. Add book coverage for R857, Biomedical Engineering. Coverage is slip notification only.

T: Technology and Engineering. The profile has a high rate of book coverage currently. In $\mathrm{TH}$, cancel book notification coverage for TH2401-2495 on Roofs. In TJ, cancel book notification coverage for TJ940-1030 on Vacuum Technology. Cancel book notification for TK454.4 on Electromagnetics. Cancel book notification for numbers in TS on Manufactures. Otherwise keep most book notification coverage in TA (General Engineering), TJ (Mechanical Engineering), TK (Electrical Engineering and Telecommunications) and TP (Chemical Technology). 


\section{Conclusions}

Through the customer survey and through circulation patterns as shown in this report, Library customers have stated that the book collection is an important and highly used resource. This report provides an outline of subject areas in which collection development will almost certainly result in resources that are highly used and generate substantial return on investment (ROI). These subjects include but are not limited to NIST SFAs. They also include many subjects of broad interest to the research community, such as spectroscopy, and of practical utility to bench scientists, such as computer programming.

The results of this report suggest that NIST staff use the book collection to learn about topics that support their research, such as programming, research methodology, and statistical analysis, as much if not more than to learn about their specific areas of expertise. Studies of information use by scientists have shown that journals, not books, are the single most important information resource for maintaining current awareness in the fields of science and engineering. ${ }^{6}$ At NIST, this study suggests that the book collection is more likely to be used to investigate fields in which the scientist is less familiar, but in which a situational need for more knowledge has occurred. Among the most popular books in the collection are a number of classic textbooks, supporting the thesis that the Library should view the book collection not only as a resource for subject experts, but also for non-experts coming in from outside a discipline to get an introduction to a new topic. In this situation, the customer is unlikely to know ahead of time the title of the book they need; therefore interlibrary loan, often cited as a partial remedy for shrinking book budgets, is an ineffective option for this customer.

In recent fiscal years, budget cuts to the Library have made collection development challenging. As the Library continues to operate with a limited book budget, it is paramount that titles purchased are effective and utilized. The Library's strategic plan for fiscal year 2005 includes developing a measure for new book circulation. In academic libraries, studies have shown that typically as many as $40 \%$ of new books do not circulate within the first three to five years on the shelf. ${ }^{\text {If }}$ the Library exceeds this mark, it would be successful compared to many other institutions. But given that the NIST Research Library is focused on the present practical needs of the NIST scientific community, and not on the long term research needs of the typical academic community, the Library should aim for a circulation rate approaching the $100 \%$ level. Table 4, Top 50 Call Numbers for New Books (1999-2004), shows that usage in many areas is very high, but a baseline for circulation of all new acquisitions has not yet been established. The Library can aim to achieve high usage of new acquisitions by close monitoring of circulation of existing resources by its customers. This study represents one attempt to do such monitoring. Repeating this study at frequent intervals would be difficult due to the large volume of data. However, similar smaller studies may be conducted more regularly based on periodic "snap shots" of circulation showing all materials on loan on a given day. The Library will explore this possibility in conjunction with the development of the measurement for new book circulation.

This report illuminates popular subject areas. High usage rates in many of these subjects, especially for new books, shows that the Library's acquisition program has been successful. Input from Subject Specialists and Strategic Working Groups has been effective. The Library has identified what its customers are reading and knows what it should be buying. The Library is ready to make sound purchasing decisions and to measure its performance. The Library book collection should continue to be funded to maintain and improve its current level of success and customer satisfaction.

\footnotetext{
${ }^{6}$ Susan Miller, Information-Seeking Behaviour of Academic Scientists in the Electronic Age: a Literature Review, Canadian Research Knowledge Network [web page], http://www.researchknowledge.ca/initiatives/evaluation/LitReview-SusanMiller.pdf [June 2002].

${ }^{7}$ Deborah Blecic, Monograph use at an academic health sciences library: the first three years of shelf life, Bull. Med. Libr. Assoc. 88 (2), 145-151 (2000). Larry Hardesty, Use of library materials at a small liberal arts college: a replication, Coll. Manage. 10 (3-4), 61-80 (1988).
} 


\section{Appendix A. Data Tables}

Table 1. LCC Classes Ranked by Score

\begin{tabular}{|c|c|c|c|c|c|}
\hline & & LCC Class & Score $^{a}$ & \begin{tabular}{|c|} 
Total \\
Transactions
\end{tabular} & Total Volumes \\
\hline 1 & $\mathrm{Q}$ & Science & 1256583.6 & 151068 & 8318 \\
\hline 2 & $\mathrm{~T}$ & Technology & 213744.9 & 58257 & 3669 \\
\hline 3 & $\mathrm{R}$ & Medicine & 503.1 & 2795 & 180 \\
\hline 4 & $\mathrm{H}$ & Social Sciences & 441.3 & 1970 & 224 \\
\hline 5 & $\mathrm{P}$ & Language and Literature & 20.6 & 527 & 39 \\
\hline 6 & $Z$ & Library Science. Information Resources. & 16.6 & 395 & 42 \\
\hline 7 & $\mathrm{~B}$ & Philosophy. Psychology. Religion & 13.7 & 456 & 30 \\
\hline 8 & $\mathrm{U}$ & Military Science & 1.8 & 91 & 23 \\
\hline 9 & $G$ & Geography. Anthropology. Recreation & 1.6 & 132 & 12 \\
\hline 10 & $S$ & Agriculture & 1.0 & 61 & 17 \\
\hline 11 & $\mathrm{~J}$ & Political Science & 0.9 & 72 & 13 \\
\hline 12 & $\mathrm{M}$ & Music & 0.7 & 100 & 7 \\
\hline 13 & $\mathrm{~K}$ & Law & 0.2 & 38 & 4 \\
\hline 14 & $\mathrm{D}$ & History (General). History of Europe & 0.1 & 29 & 4 \\
\hline 15 & $\mathrm{~N}$ & Fine Arts & 0.1 & 25 & 4 \\
\hline 16 & $\mathrm{C}$ & Auxiliary Sciences of History & 0.1 & 16 & 5 \\
\hline 17 & $\mathrm{~L}$ & Education & 0.1 & 37 & 2 \\
\hline 18 & $\mathrm{~V}$ & Naval Science & 0.0 & 4 & 3 \\
\hline 19 & $A$ & General Works & 0.0 & 10 & 1 \\
\hline
\end{tabular}

${ }^{\mathrm{a}}$ Score $=$ Total Circulation Transactions $\times$ Total Circulated Volumes $/ 1000$ 


\section{Table 2. NIST Modified Subclasses Ranked by Score ${ }^{a}$}

\begin{tabular}{|c|c|c|c|c|c|}
\hline & \multicolumn{2}{|r|}{ Subclass $^{b}$} & Score $^{c}$ & Total & Total Volumes \\
\hline 1 & QC & Physics & 161418.5 & 53896 & 2995 \\
\hline 2 & QA, pt.1 & Mathematics & 79105.9 & 36404 & 2173 \\
\hline 3 & QD & Chemistry & 55626.2 & 32473 & 1713 \\
\hline 4 & TA & Engineering, General & 25683.5 & 21191 & 1212 \\
\hline 5 & QA, pt.2 & Computer Science & 9288.1 & 14650 & 634 \\
\hline 6 & TK, pt.1 & Electrical Engineering & 4820.8 & 8578 & 562 \\
\hline 7 & TJ & Mechanical Engineering & 3256.3 & 6461 & 504 \\
\hline 8 & TP, pt.1 & Chemical Technology, General & 2255.3 & 6537 & 345 \\
\hline 9 & TK, pt.2 & Telecommunications & 1355.9 & 4808 & 282 \\
\hline 10 & QP, pt.1 & Biochemistry & 1279.0 & 5374 & 238 \\
\hline 11 & $Q$ & Science, General & 874.2 & 3511 & 249 \\
\hline 12 & $\mathrm{~T}$ & Technology, General & 645.8 & 3090 & 209 \\
\hline 13 & TS & Manufactures & 490.8 & 2653 & 185 \\
\hline 14 & TN & Metallurgy & 405.4 & 2599 & 156 \\
\hline 15 & QH, pt.1 & Biology, General & 189.1 & 1735 & 109 \\
\hline 16 & $\mathrm{QH}$, pt.2 & Microscopy & $\overline{126.6}$ & 1666 & 76 \\
\hline 17 & R, pt.1 & Bioengineering & 104.2 & 1488 & 70 \\
\hline 18 & $\mathrm{HD}$ & Management & 95.7 & 870 & 110 \\
\hline 19 & $\mathrm{TH}$ & Building Construction & 43.3 & 577 & 75 \\
\hline 20 & QB & Astronomy & 31.7 & 529 & 60 \\
\hline 21 & $\mathrm{HF}$ & Commerce & 31.2 & 547 & 57 \\
\hline 22 & TD & Environmental Technology & 27.6 & 673 & 41 \\
\hline 23 & QE & Geology & 15.3 & 478 & 32 \\
\hline 24 & QP, pt.2 & Physiology, General & 9.7 & 304 & 32 \\
\hline 25 & TP, pt.2 & Biotechnology & 9.6 & 371 & 26 \\
\hline 26 & RC-RF & Medicine, Specialties & 9.5 & 450 & 21 \\
\hline 27 & $\mathrm{BF}$ & Psychology & 8.6 & 391 & 22 \\
\hline 28 & $\mathrm{TL}$, pt.1 & Aeronautics and Astronautics & 8.0 & 268 & 30 \\
\hline 29 & RM-RS & Pharmacology & 7.9 & 374 & 21 \\
\hline 30 & RA, pt.1 & Toxicology & 7.1 & 173 & 41 \\
\hline 31 & $\mathrm{H}, \mathrm{HA}$ & Statistics & 5.3 & 250 & 21 \\
\hline
\end{tabular}

\footnotetext{
a Some LCC subclasses were divided and others combined based on local practice and terminology.

${ }^{\mathrm{b}}$ Includes subclasses scoring 5 or higher

${ }^{c}$ Score $=$ Total Circulation Transactions $x$ Total Circulated Volumes $/ 1000$
} 
Table 3. Top 100 Call Numbers for All Books Ranked by Score

\begin{tabular}{|c|c|c|c|c|c|c|c|c|c|}
\hline Rank & Score $^{a}$ & Subject Area & Topic & Call Number & $\begin{array}{c}\text { Circ. } \\
\text { Trans- } \\
\text { actions }\end{array}$ & $\begin{array}{l}\text { Circu- } \\
\text { lated } \\
\text { Vols. }\end{array}$ & $\begin{array}{c}\text { Circ. } \\
\text { Trans. I } \\
\text { Circ. } \\
\text { Vols. }\end{array}$ & $\begin{array}{c}\text { Available } \\
\text { Vols. On } \\
\text { Shelf }\end{array}$ & $\begin{array}{c}\text { Usage } \\
\text { Rate of } \\
\text { Available } \\
\text { Vols. }\end{array}$ \\
\hline 1 & 550.3 & Analytical Chemistry & Spectrum Analysis, Special & QD96 & 3693 & 149 & 24.8 & 262 & $57 \%$ \\
\hline 2 & 344.6 & Optics. Light & Spectroscopy, Special & $\overline{Q C 454}$ & 2692 & 128 & 21.0 & 274 & $47 \%$ \\
\hline 3 & 327.8 & $\begin{array}{l}\text { Computers and Special } \\
\text { Computing }\end{array}$ & $\begin{array}{l}\text { Computer Topics: Security, Client/Server, } \\
\text { Simulation, Natural Language, etc. }\end{array}$ & QA76.9 & 2325 & 141 & 16.5 & 702 & $20 \%$ \\
\hline 4 & 281.1 & Atomic Physics & Solids. Solid State Physics & QC176.8 ${ }^{\mathrm{d}}$ & 2037 & 138 & 14.8 & 267 & $52 \%$ \\
\hline 5 & 172.1 & Programming & C Programming Languages $(\mathrm{C}, \mathrm{C}++, \mathrm{C \#})$ & QA76.73.C15x & 2822 & 61 & 46.3 & 83 & $73 \%$ \\
\hline 6 & 156.9 & Mathematical Statistics & Mathematical Statistics, General & QA276 & 1846 & 85 & 21.7 & 237 & $36 \%$ \\
\hline 7 & 109.9 & Probabilities & Probabilities, General & QA273 & 1616 & 68 & 23.8 & 235 & $29 \%$ \\
\hline 8 & 109.7 & Nuclear Physics & $\begin{array}{l}\text { Special Particles, Antiparticles, Families } \\
\text { of Particles }\end{array}$ & QC793.5 & 1407 & 78 & 18.0 & 258 & $30 \%$ \\
\hline 9 & 104.8 & Materials of Engineering & Polymers & TA455 .P58 & 1691 & 62 & 27.3 & 84 & $74 \%$ \\
\hline 10 & 103.1 & Inorganic Chemistry & Special Inorganic Elements & QD181 & 1375 & 75 & 18.3 & 273 & $27 \%$ \\
\hline 11 & 95.8 & Electronics & Semiconductors & TK7871.85 & 1330 & 72 & 18.5 & 217 & $33 \%$ \\
\hline 12 & 85.1 & Organic Chemistry & Polymers. Macromolecules, General & QD381 & 1606 & 53 & 30.3 & 79 & $67 \%$ \\
\hline 13 & 84.3 & Programming & Programming Languages & QA76.73 & 1533 & 55 & 27.9 & 161 & $34 \%$ \\
\hline 14 & 82.2 & Biochemistry & $\begin{array}{l}\text { Biochemistry Technique. Analytical } \\
\text { Biochemistry, Special. }\end{array}$ & QP519.9 & 1394 & 59 & 23.6 & 124 & $48 \%$ \\
\hline 15 & 81.8 & Biomedical Engineering & $\begin{array}{l}\text { Bioengineering Topics: Biosensors, } \\
\text { Materials, Polymers, etc. }\end{array}$ & $\mathrm{R} 857$ & 1320 & 62 & 21.3 & 94 & $66 \%$ \\
\hline 16 & 80.4 & $\begin{array}{l}\text { Physical and Theoretical } \\
\text { Chemistry }\end{array}$ & $\begin{array}{l}\text { Atomic and Molecular Theory and } \\
\text { Structure }\end{array}$ & QD461 & 1148 & 70 & 16.4 & 211 & $33 \%$ \\
\hline
\end{tabular}

\footnotetext{
${ }^{\text {a }}$ Score $=$ Total Circulation Transactions $x$ Total Circulated Volumes $/ 1000$

b Underlined Call Numbers represent numbers that further subdivide into multiple topics. Sample subtopics shown in Table 5

c Except QA76.9 .D3 (Database Management) which qualified for scoring independently.

d Except QC176.8 .E4 (Electronic States) which qualified for scoring independently.

except QA76.73 .C15 (C Languages) and .J38 (Java) which qualified for scoring independently.
} 


\begin{tabular}{|c|c|c|c|c|c|c|c|c|c|}
\hline Rank & Score & Subject Area & Specific Topic & Call Number & $\begin{array}{c}\text { Circ. } \\
\text { Trans- } \\
\text { actions }\end{array}$ & $\begin{array}{l}\text { Circu- } \\
\text { lated } \\
\text { Vols. }\end{array}$ & $\begin{array}{c}\text { Circ. } \\
\text { Trans. I } \\
\text { Circ. } \\
\text { Vols. }\end{array}$ & $\begin{array}{c}\text { Available } \\
\text { Vols. On } \\
\text { Shelf }\end{array}$ & $\begin{array}{c}\text { Usage } \\
\text { Rate of } \\
\text { Available } \\
\text { Vols. }\end{array}$ \\
\hline 17 & 69.9 & Atomic Physics & Solid State Physics, General & QC176 & 1227 & 57 & 21.5 & 189 & $35 \%$ \\
\hline 18 & 69.4 & Mathematical Physics & Mathematical Physics, Special & QC20.7 & 1036 & 67 & 15.5 & 97 & $52 \%$ \\
\hline 19 & 60.1 & Electricity & Semiconductor Physics, Special & QC611.6 & 1202 & 50 & 24.0 & 86 & $55 \%$ \\
\hline 20 & 58.0 & Biochemistry & Proteins & QP551 & 1234 & 47 & 26.3 & 131 & $44 \%$ \\
\hline 21 & 56.6 & Atomic Physics & Quantum Theory \& Mechanics, General & QC174.12 & 871 & 65 & 13.4 & 154 & $42 \%$ \\
\hline 22 & 55.9 & Electronics & Microelectronics & TK7874 & 1036 & 54 & 19.2 & 325 & $17 \%$ \\
\hline 23 & 55.9 & Chemical Engineering & Special Processes \& Operations & $\underline{\text { TP156 }}$ & 998 & 56 & 17.8 & 217 & $26 \%$ \\
\hline 24 & 52.7 & Mathematical Statistics & Nonparametric Methods & QA279 & 1053 & 50 & 21.1 & 90 & $56 \%$ \\
\hline 25 & 52.3 & Mathematical Analysis & Numerical Analysis & QA297 & 968 & 54 & 17.9 & 152 & $36 \%$ \\
\hline 26 & 52.1 & Programming & Java Language & QA76.73 .J38 & 1211 & 43 & 28.2 & 61 & $70 \%$ \\
\hline 27 & 49.2 & Mathematical Statistics & Regression \& Correlations Analysis & QA278.2 & 1144 & 43 & 26.6 & 74 & $58 \%$ \\
\hline 28 & 47.9 & Atomic Physics & Statistical Physics, General & QC174.8 & 1114 & 43 & 25.9 & 64 & $67 \%$ \\
\hline 29 & 47.8 & Atomic Physics & Matter and Antimatter, Spec. & QC173.4 & 1038 & 46 & 22.6 & 143 & $32 \%$ \\
\hline 30 & 46.9 & Mathematical Statistics & Multivariate Analysis & QA278 & 938 & 50 & 18.8 & 89 & $56 \%$ \\
\hline 31 & 46.6 & Analytical Chemistry & Chromatographic Analysis & $\begin{array}{l}\text { QD79.C4 - } \\
\text { QD79.C8 }\end{array}$ & 991 & 47 & 21.1 & 50 & $94 \%$ \\
\hline 32 & 44.4 & Optics. Light & Optics, General & $\begin{array}{l}\text { QC355 - } \\
\text { QC355.2 } \\
\end{array}$ & 1199 & 37 & 32.4 & 65 & $57 \%$ \\
\hline 33 & 43.9 & Metallography & Metallography, General & TN690 & 1097 & 40 & 27.4 & 144 & $28 \%$ \\
\hline 34 & 40.0 & $\begin{array}{l}\text { Robotics and Automatic } \\
\text { Machinery }\end{array}$ & $\begin{array}{l}\text { Robotics and Automatic Machinery, } \\
\text { General }\end{array}$ & TJ211 & 728 & 55 & 13.2 & 114 & $48 \%$ \\
\hline 35 & 38.7 & Software & $\begin{array}{l}\text { Operating Systems (Windows, Linux, } \\
\text { Unix) }\end{array}$ & QA76.76.063 & 944 & 41 & 23.0 & 162 & $25 \%$ \\
\hline 36 & 38.1 & Applied Optics & Optical Data Processing & TA1632 & 976 & 39 & 25.0 & 229 & $17 \%$ \\
\hline 37 & 37.8 & Atomic Physics & Quantum Theory \& Mechanics, Special & $\underline{\mathrm{QC} 174.17}$ & 756 & 50 & 15.1 & 165 & $30 \%$ \\
\hline 38 & 34.7 & Software & Software Topics & $\underline{\text { QA76.76 }}^{\mathrm{g}}$ & 722 & 45 & 17.2 & 158 & $28 \%$ \\
\hline
\end{tabular}

\footnotetext{
${ }^{f}$ Except QC173.4 .S94 (Surfaces) which qualified for scoring independently.

${ }^{9}$ Except QA76.76 .E95 (Expert Systems), .H94 (Hypertext Systems) and .O63 (Operating Systems) which qualified for scoring independently.
} 


\begin{tabular}{|c|c|c|c|c|c|c|c|c|c|}
\hline Rank & Score & Subject Area & Specific Topic & Call Number & $\begin{array}{c}\text { Circ. } \\
\text { Trans- } \\
\text { actions }\end{array}$ & $\begin{array}{l}\text { Circu- } \\
\text { lated } \\
\text { Vols. }\end{array}$ & $\begin{array}{c}\text { Circ. } \\
\text { Trans. I } \\
\text { Circ. } \\
\text { Vols. }\end{array}$ & $\begin{array}{c}\text { Available } \\
\text { Vols. On } \\
\text { Shelf }\end{array}$ & $\begin{array}{c}\text { Usage } \\
\text { Rate of } \\
\text { Available } \\
\text { Vols. }\end{array}$ \\
\hline 39 & 33.8 & Probabilities & Markov Processes \& Chains & QA274.7x & 845 & 40 & 21.1 & 82 & $49 \%$ \\
\hline 40 & 32.2 & Organic Chemistry & $\begin{array}{l}\text { Polymers. Macromolecules, Special } \\
\text { Topics }\end{array}$ & QD381.9 & 895 & 36 & 24.9 & 62 & $58 \%$ \\
\hline 41 & 32.1 & Electronics & Apparatus and Materials & TK7872 & 583 & 55 & 10.6 & 227 & $24 \%$ \\
\hline 42 & 31.2 & Probabilities & Distributions. & QA273.6 & 822 & 38 & 21.6 & 46 & $83 \%$ \\
\hline 43 & 30.3 & Heat & Heat Transfer & QC320 & 948 & 32 & 29.6 & 48 & $67 \%$ \\
\hline 44 & 29.6 & Telecommunication & Telecommunication, Special & TK5102.5 & 988 & 30 & 32.9 & 92 & $33 \%$ \\
\hline 45 & 29.4 & Mathematical Analysis & Control Theory & QA402.3x & 577 & 51 & 11.3 & 168 & $30 \%$ \\
\hline 46 & 28.3 & Analytical Mechanics & Elasticity. Plasticity & QA931 & 808 & 35 & 23.1 & 91 & $38 \%$ \\
\hline 47 & 28.0 & Mathematical Analysis & Mathematical Optimization. Programming & QA402.5 & 609 & 46 & 13.2 & 151 & $30 \%$ \\
\hline 48 & 27.8 & Applied Optics & Image Processing & TA1637 & 795 & 35 & 22.7 & 58 & $60 \%$ \\
\hline 49 & 27.4 & Mechanical Drawing & Computer Graphics & T385 & 762 & 36 & 21.2 & 117 & $31 \%$ \\
\hline 50 & 27.4 & Electronics & Materials, Special & TK7871.15 & 831 & 33 & 25.2 & 86 & $38 \%$ \\
\hline 51 & 27.1 & Materials of Engineering & Composite Materials & TA418.9.C6 & 661 & 41 & 16.1 & 155 & $26 \%$ \\
\hline 52 & 26.2 & $\begin{array}{l}\text { Control Engineering } \\
\text { Systems }\end{array}$ & Control Engineering Systems, General & TJ213 & 494 & 53 & 9.3 & 117 & $45 \%$ \\
\hline 53 & 26.0 & Heat & Thermodynamics & QC311 & 684 & 38 & 18.0 & 92 & $41 \%$ \\
\hline 54 & 24.8 & Crystallography & Crystal Structure and Growth & QD921 & 637 & 39 & 16.3 & 150 & $26 \%$ \\
\hline 55 & 24.8 & Algebra & Group Theory & QA171 & 605 & 41 & 14.8 & 177 & $23 \%$ \\
\hline 56 & 24.5 & Optics. Light & Nonlinear \& Quantum Optics & QC446.2 & 790 & 31 & 25.5 & 48 & $65 \%$ \\
\hline 57 & 24.4 & $\begin{array}{l}\text { Physical and Theoretical } \\
\text { Chemistry }\end{array}$ & Surface Chemistry & QD506 & 764 & 32 & 23.9 & 107 & $30 \%$ \\
\hline 58 & 23.2 & Atomic Physics & Quantum Field Theory & QC174.45 & 539 & 43 & 12.5 & 113 & $38 \%$ \\
\hline 59 & 22.5 & Microscopy & Scanning Microscopes & QH212.S3x & 704 & 32 & 22.0 & 33 & $97 \%$ \\
\hline 60 & 22.0 & Analytical Mechanics & Fluid Dynamics. Hydraulics & QA911 & 687 & 32 & 21.5 & 93 & $34 \%$ \\
\hline 61 & 21.6 & $\begin{array}{l}\text { Computers and Special } \\
\text { Computing }\end{array}$ & Neural Computers \& Networks & QA76.87 & 721 & 30 & 24.0 & 100 & $30 \%$ \\
\hline 62 & 21.3 & Mathematical Statistics & Time Series Analysis & QA280 & 644 & 33 & 19.5 & 79 & $42 \%$ \\
\hline \begin{tabular}{r|}
63 \\
\end{tabular} & 20.7 & Radiation Physics & X-Rays \& Roentgen Rays & $\underline{\mathrm{QC} 482}$ & 738 & 28 & 26.4 & 40 & $70 \%$ \\
\hline
\end{tabular}




\begin{tabular}{|c|c|c|c|c|c|c|c|c|c|}
\hline Rank & Score & Subject Area & Specific Topic & Call Number & $\begin{array}{c}\text { Circ. } \\
\text { Trans- } \\
\text { actions }\end{array}$ & $\begin{array}{l}\text { Circu- } \\
\text { lated } \\
\text { Vols. }\end{array}$ & $\begin{array}{c}\text { Circ. } \\
\text { Trans. I } \\
\text { Circ. } \\
\text { Vols. }\end{array}$ & $\begin{array}{c}\text { Available } \\
\text { Vols. On } \\
\text { Shelf }\end{array}$ & $\begin{array}{c}\text { Usage } \\
\text { Rate of } \\
\text { Available } \\
\text { Vols. }\end{array}$ \\
\hline 64 & 20.1 & $\begin{array}{l}\text { Mechanics of } \\
\text { Engineering }\end{array}$ & Applied Fluid Mechanics & TA357 & 772 & 26 & 29.7 & 86 & $30 \%$ \\
\hline 65 & 19.8 & Atomic Physics & Electronic States & QC176.8.E4 & 599 & 33 & 18.2 & 98 & $34 \%$ \\
\hline 66 & 18.5 & $\begin{array}{l}\text { Physical and Theoretical } \\
\text { Chemistry }\end{array}$ & Chemical Reactions & QD501 & 543 & 34 & 16.0 & 208 & $16 \%$ \\
\hline 67 & 18.4 & Analytical Chemistry & Analytical Chemistry, Special & QD75.4 & 736 & 25 & 29.4 & 48 & $52 \%$ \\
\hline 68 & 17.7 & Cybernetics & Artificial Intelligence & Q335 & 507 & 35 & 14.5 & 112 & $31 \%$ \\
\hline 69 & 17.7 & Materials of Engineering & Nonmetallic Materials & TA455 $^{\mathrm{h}}$ & 571 & 31 & 18.4 & 138 & $22 \%$ \\
\hline 70 & 17.7 & Geometry & Topology & QA611 & 491 & 36 & 13.6 & 106 & $34 \%$ \\
\hline 71 & 17.5 & Materials of Engineering & Surface Effects and Tests & TA418.7 & 731 & 24 & 30.5 & 49 & $49 \%$ \\
\hline 72 & 17.3 & Machinery & Tribology. Lubrication and Friction & TJ1075 & 642 & 27 & 23.8 & 82 & $33 \%$ \\
\hline 73 & 17.3 & Atomic Physics & Matter and Antimatter, General & QC173 & 596 & 29 & 20.6 & 196 & $15 \%$ \\
\hline 74 & 17.0 & Crystallography & X-Ray Crystallography & QD945 & 630 & 27 & 23.3 & 69 & $39 \%$ \\
\hline 75 & 16.8 & Mathematical Analysis & Differential Equations & QA371 & 509 & 33 & 15.4 & 152 & $22 \%$ \\
\hline 76 & 16.8 & Software & Hypertext Systems (Inc. HTML \& XML) & QA76.76.H94 & 670 & 25 & 26.8 & 35 & $71 \%$ \\
\hline 77 & 16.7 & $\begin{array}{l}\text { Computers and Special } \\
\text { Computing }\end{array}$ & Database Management & QA76.9.D3 & 575 & 29 & 19.8 & 198 & $15 \%$ \\
\hline 78 & 16.3 & Atomic Physics & Statistical Physics, Special & QC174.85 & 563 & 29 & 19.4 & 52 & $56 \%$ \\
\hline 79 & 16.3 & Telecommunication & Optical Communications & TK5103.59 & 604 & 27 & 22.4 & 72 & $38 \%$ \\
\hline 80 & 16.3 & Magnetism & Magnetism, General & $\begin{array}{l}\text { QC753 - } \\
\text { QC753.2 }\end{array}$ & 652 & 25 & 26.1 & 39 & $64 \%$ \\
\hline 81 & 16.0 & Telecommunication & World Wide Web & TK5105.888 & 484 & 33 & 14.7 & 49 & $67 \%$ \\
\hline 82 & 15.6 & Electricity & Semiconductors & QC612.S4 & 489 & 32 & 15.3 & 48 & $67 \%$ \\
\hline 83 & 15.5 & $\begin{array}{l}\text { Physical and Theoretical } \\
\text { Chemistry }\end{array}$ & $\begin{array}{l}\text { Physical and Theoretical Chemistry, } \\
\text { General }\end{array}$ & $\begin{array}{l}\text { QD453 - } \\
\text { QD453.2 }\end{array}$ & 500 & 31 & 16.1 & 92 & $34 \%$ \\
\hline 84 & 15.2 & Chemistry & Chemistry, Special Topics & QD39.3 & 491 & 31 & 15.8 & 44 & $70 \%$ \\
\hline
\end{tabular}

\footnotetext{
${ }^{\mathrm{h}}$ Except TA455 .P58 (Polymers) which qualified for scoring independently.
} 


\begin{tabular}{|c|c|c|c|c|c|c|c|c|c|}
\hline Rank & Score & Subject Area & Specific Topic & Call Number & $\begin{array}{c}\text { Circ. } \\
\text { Trans- } \\
\text { actions }\end{array}$ & $\begin{array}{l}\text { Circu- } \\
\text { lated } \\
\text { Vols. }\end{array}$ & $\begin{array}{l}\text { Circ. } \\
\text { Trans. I } \\
\text { Circ. } \\
\text { Vols. }\end{array}$ & $\begin{array}{c}\text { Available } \\
\text { Vols. On } \\
\text { Shelf }\end{array}$ & $\begin{array}{c}\text { Usage } \\
\text { Rate of } \\
\text { Available } \\
\text { Vols. }\end{array}$ \\
\hline 85 & 15.2 & $\begin{array}{l}\text { Engineering } \\
\text { Mathematics }\end{array}$ & $\begin{array}{l}\text { Finite Element Method of Problem } \\
\text { Solving }\end{array}$ & TA347.F5 & 585 & 26 & 22.5 & 50 & $52 \%$ \\
\hline 86 & 14.6 & Electricity & Electromagnetic Theory & QC670 & 442 & 33 & 13.4 & 77 & $43 \%$ \\
\hline 87 & 14.4 & Materials of Engineering & Failure of Materials. & TA409 & 464 & 31 & 15.0 & 115 & $27 \%$ \\
\hline 88 & 14.3 & Electricity & Semiconductor Physics, General & QC611 & 509 & 28 & 18.2 & 70 & $40 \%$ \\
\hline 89 & 13.9 & Mathematical Analysis & Partial Differential Equations & QA377 & 385 & 36 & 10.7 & 119 & $30 \%$ \\
\hline 90 & 13.8 & Organic Chemistry & Polymerization. Telomerization. & QD281.P6 & 532 & 26 & 17.6 & 76 & $37 \%$ \\
\hline 91 & 13.8 & $\begin{array}{l}\text { Physical and Theoretical } \\
\text { Chemistry }\end{array}$ & Quantum Chemistry & QD462 & 494 & 28 & 20.5 & 81 & $32 \%$ \\
\hline 92 & 13.1 & Telecommunication & Computer Networks & TK5105.5 & 505 & 26 & 19.4 & 144 & $18 \%$ \\
\hline 93 & 12.6 & Probabilities & Stochastic Analysis & QA274.2x & 466 & 27 & 17.3 & 52 & $52 \%$ \\
\hline 94 & 12.4 & Mathematical Analysis & System Analysis & QA402 & 460 & 27 & 17.0 & 118 & $23 \%$ \\
\hline 95 & 12.4 & Software & Expert Systems & QA76.76.E95 & 459 & 27 & 17.0 & 116 & $23 \%$ \\
\hline 96 & 11.9 & \begin{tabular}{|l|} 
Engineering \\
Mathematics \\
\end{tabular} & $\begin{array}{l}\text { Computer-Aided Engineering. Data } \\
\text { Processing. }\end{array}$ & TA345 & 459 & 26 & 17.7 & 74 & $35 \%$ \\
\hline 97 & 11.9 & Electricity & Superconductivity Physics, Spec. & QC612 $^{\mathrm{i}}$ & 497 & 24 & 20.7 & 72 & $33 \%$ \\
\hline 98 & 11.5 & Nuclear Physics & Elementary Particle Physics & $\underline{Q C 793.3}$ & 409 & 28 & 14.6 & 173 & $16 \%$ \\
\hline 99 & 11.5 & Atomic Physics & Surfaces & QC173.4.S94 & 458 & 25 & 18.3 & 68 & $37 \%$ \\
\hline 100 & 11.0 & Physicists Biographies & Individual Biographies & QC16 & 345 & 32 & 10.8 & 103 & $31 \%$ \\
\hline
\end{tabular}

\footnotetext{
'Except QC612 .S4 (Semiconductors) which qualified for scoring independently.
} 


\section{Table 4. Top 50 Call Numbers for New Books (1999-2004) Ranked by Score}

\begin{tabular}{|c|c|c|c|c|c|c|c|c|c|}
\hline Rank & Score $^{a}$ & Subject Area & Specific Topic $^{b}$ & Call Number & $\begin{array}{l}\text { Circ. } \\
\text { Trans- } \\
\text { actions }\end{array}$ & $\begin{array}{l}\text { Circu- } \\
\text { lated } \\
\text { Vols. }\end{array}$ & $\begin{array}{c}\text { Circ. } \\
\text { Trans. I } \\
\text { Circ. } \\
\text { Vols. }\end{array}$ & $\begin{array}{c}\text { Available } \\
\text { Vols. On } \\
\text { Shelf }\end{array}$ & $\begin{array}{c}\text { Usage } \\
\text { Rate of } \\
\text { Available } \\
\text { Vols. } \\
\end{array}$ \\
\hline 1 & 100.3 & Software & Operating Systems (Windows, Linux, Unix) & QA76.76.063 & 418 & 24 & 17.4 & 25 & $96 \%$ \\
\hline 2 & 98.7 & Programming & Java Language & QA76.73 .J38 & 429 & 23 & 18.7 & 23 & $100 \%$ \\
\hline 3 & 29.7 & Software & Hypertext Systems (Inc. HTML \& XML) & QA76.76.H94 & 270 & 11 & 24.5 & 11 & $100 \%$ \\
\hline 4 & 26.8 & Telecommunication & World Wide Web & TK5105.888 & 149 & 18 & 8.3 & 25 & $72 \%$ \\
\hline 5 & 26.2 & Materials of Engineering & Nanostructure Materials & TA418.9 .N35 & 164 & 16 & 10.3 & 16 & $100 \%$ \\
\hline 6 & 24.1 & Atomic Physics & Solids. Solid State Physics. Special & QC176.8 & 134 & 18 & 7.4 & 27 & $67 \%$ \\
\hline 7 & 17.9 & Atomic Physics & Quantum Theory \& Mechanics, General & $\overline{Q C 174.12}$ & 138 & 13 & 10.6 & 21 & $62 \%$ \\
\hline 8 & 15.6 & Software & Software Topics, Special & $\underline{Q A 76.76}^{\mathrm{d}}$ & 120 & 13 & 9.2 & 54 & $24 \%$ \\
\hline 9 & 13.5 & Analytical Chemistry & Spectrum Analysis, Special & QD96 & 123 & 11 & 11.2 & 15 & $73 \%$ \\
\hline 10 & 13.4 & $\begin{array}{l}\text { Computers and Special } \\
\text { Computing }\end{array}$ & Computer Topics, Special & ${\underline{\mathrm{QA}} 76.9^{\mathrm{e}}}$ & 103 & 13 & 7.9 & 30 & $43 \%$ \\
\hline 11 & 12.8 & $\begin{array}{l}\text { Computers and Special } \\
\text { Computing }\end{array}$ & Database Management & QA76.9 .D3 & 128 & 10 & 12.8 & 12 & $83 \%$ \\
\hline 12 & 12.2 & Technology, General & Nanotechnology & T174.7 & 111 & 11 & 10.1 & 14 & $79 \%$ \\
\hline 13 & 12.0 & Mathematical Statistics & Bayesian Statistics & QA279.5 & 133 & 9 & 14.8 & 12 & $75 \%$ \\
\hline 14 & 11.7 & $\begin{array}{l}\text { Engineering } \\
\text { Mathematics }\end{array}$ & $\begin{array}{l}\text { Computer-Aided Engineering. Data } \\
\text { Processing. }\end{array}$ & TA345 & 130 & 9 & 14.4 & 9 & $100 \%$ \\
\hline 15 & 11.4 & Electronics & Semiconductors & TK7871.85 & 95 & 12 & 7.9 & 13 & $92 \%$ \\
\hline 16 & 11.4 & Telecommunication & Signal Processing & TK5102.9 & 142 & 8 & 17.8 & 9 & $89 \%$ \\
\hline 17 & 10.8 & Programming & Programming Languages & $\underline{Q A 76.73}^{\dagger}$ & 154 & 7 & 22 & 9 & $78 \%$ \\
\hline
\end{tabular}

\footnotetext{
a Score $=$ Total Circulation Transactions $\times$ Total Circulated Volumes $/ 100$

b Specific Topics shown in shade are topics that did not appear in the list of Top 100 Call Numbers for All Books. These should be considered emerging topics of interest to the NIST community in the period 1999-2004.

${ }^{c}$ Underlined Call Numbers represent numbers that further subdivide into multiple topics. Sample subtopics shown in Table 5.

d Except QA76.76 .H94 (Hypertext Systems) and .O63 (Operating Systems) which qualified for scoring independently.

except QA76.9 .C55 (Client/Server), .D26 (Database Design), .D3 (Database Management), and .O35 (Object-Oriented Methods) which qualified for scoring independently.

f Except QA76.73 .C15x (C Languages), .B3 (Visual Basic), and .J38 (Java) which qualified for scoring independently.
} 


\begin{tabular}{|c|c|c|c|c|c|c|c|c|c|}
\hline Rank & Score & Subject Area & Specific Topic & Call Number & $\begin{array}{c}\text { Circ. } \\
\text { Trans- } \\
\text { actions }\end{array}$ & $\begin{array}{l}\text { Circu- } \\
\text { lated } \\
\text { Vols. }\end{array}$ & $\begin{array}{c}\text { Circ. } \\
\text { Trans. I } \\
\text { Circ. } \\
\text { Vols. }\end{array}$ & \begin{tabular}{|c|} 
Available \\
Vols. On \\
Shelf
\end{tabular} & $\begin{array}{c}\text { Usage } \\
\text { Rate of } \\
\text { Available } \\
\text { Vols. }\end{array}$ \\
\hline 18 & 10.3 & Electronics & Microelectromechanical Systems & TK7875 & 79 & 13 & 6.1 & 15 & $87 \%$ \\
\hline 19 & 9.2 & $\begin{array}{l}\text { Biomedical } \\
\text { Engineering }\end{array}$ & Biomedical Engineering, General & $\mathrm{R} 857^{\mathrm{g}}$ & 132 & 7 & 18.9 & 10 & $70 \%$ \\
\hline 20 & 8.5 & Atomic Physics & Matter and Antimatter, Special & $\overline{\mathrm{QC} 173.4}$ & 94 & 9 & 10.4 & 20 & $45 \%$ \\
\hline 21 & 8.3 & Applied Optics & Image Processing & $\overline{\text { TA1637 }}$ & 75 & 11 & 6.8 & 12 & $92 \%$ \\
\hline 22 & 7.8 & Optics. Light & Nonlinear \& Quantum Optics & QC446.2 & 98 & 8 & 12.3 & 10 & $80 \%$ \\
\hline 23 & 7.5 & Optics. Light & Spectroscopy, Special & QC454 & 83 & 9 & 9.2 & 11 & $82 \%$ \\
\hline 24 & 7.1 & $\begin{array}{l}\text { Materials of } \\
\text { Engineering }\end{array}$ & Materials of Special Composition & TA418.9 $^{\mathrm{h}}$ & 71 & 10 & 7.1 & 10 & $100 \%$ \\
\hline 25 & 6.3 & Mathematical Statistics & Nonparametric Methods & $\overline{\text { QA279 }}$ & 79 & 8 & 9.9 & 24 & $33 \%$ \\
\hline 26 & 5.8 & Atomic Physics & Statistical Physics, Special & QC174.85 & 83 & 7 & 11.9 & 7 & $100 \%$ \\
\hline 27 & 5.6 & $\begin{array}{l}\text { Physical and } \\
\text { Theoretical Chemistry }\end{array}$ & Quantum Chemistry & QD462 & 111 & 5 & 22.2 & 5 & $100 \%$ \\
\hline 28 & 5.3 & $\begin{array}{l}\text { Physical and } \\
\text { Theoretical Chemistry }\end{array}$ & $\begin{array}{l}\text { Physical and Theoretical Chemistry, } \\
\text { General }\end{array}$ & $\begin{array}{l}\text { QD453 - } \\
\text { QD453.2 }\end{array}$ & 106 & 5 & 21.2 & 5 & $100 \%$ \\
\hline 29 & 5.3 & Telecommunication & TCP/IP & TK5105.585 & 88 & 6 & 14.7 & 8 & $75 \%$ \\
\hline 30 & 5.3 & Telecommunication & Active Server Pages & $\begin{array}{l}\text { TK5105.8885 } \\
. \text { A26 }\end{array}$ & 75 & 7 & 10.7 & 7 & $100 \%$ \\
\hline 31 & 5.1 & Mechanical Drawing & Computer Graphics & T385 & 73 & 7 & 10.4 & 9 & $78 \%$ \\
\hline 32 & 4.9 & Optics. Light & Optics, General & QC355.2 & 122 & 4 & 30.5 & 4 & $100 \%$ \\
\hline 33 & 4.9 & $\begin{array}{l}\text { Biomedical } \\
\text { Engineering }\end{array}$ & Biomedical Materials & R857 .M3 & 97 & 5 & 19.4 & 5 & $100 \%$ \\
\hline 34 & 4.8 & Organic Chemistry & Polymers. Macromolecules, Special & QD381.9 & 80 & 6 & 13.3 & 6 & $100 \%$ \\
\hline 35 & 4.8 & $\begin{array}{l}\text { Computers and } \\
\text { Special Computing }\end{array}$ & Object Oriented Methods & QA76.9.035 & 95 & 5 & 19.0 & 6 & $83 \%$ \\
\hline 36 & 4.6 & Programming & C Programming Languages $(\mathrm{C}, \mathrm{C}++, \mathrm{C \#})$ & $\begin{array}{l}\text { QA76.73 } \\
. \text { C15x }\end{array}$ & 57 & 8 & 7.1 & 9 & $89 \%$ \\
\hline 37 & 4.5 & Biochemistry & Proteins & QP551 & 113 & 4 & 28.3 & 5 & $80 \%$ \\
\hline 38 & 4.4 & Analytical Chemistry & Methods of Analysis & QD79 & 73 & 6 & 12.2 & 6 & $100 \%$ \\
\hline
\end{tabular}

\footnotetext{
${ }^{9}$ Except R857 .M3 (Biomedical Materials) which qualified for scoring independently.

${ }^{\mathrm{h}}$ Except TA418.9 .N35 (Nanostructure Materials) which qualified for scoring independently.
} 


\begin{tabular}{|c|c|c|c|c|c|c|c|c|c|}
\hline Rank & Score & Subject Area & Specific Topic & Call Number & $\begin{array}{c}\text { Circ. } \\
\text { Trans- } \\
\text { actions }\end{array}$ & $\begin{array}{l}\text { Circu- } \\
\text { lated } \\
\text { Vols. }\end{array}$ & $\begin{array}{c}\text { Circ. } \\
\text { Trans. I } \\
\text { Circ. } \\
\text { Vols. }\end{array}$ & $\begin{array}{c}\text { Available } \\
\text { Vols. On } \\
\text { Shelf }\end{array}$ & $\begin{array}{c}\text { Usage } \\
\text { Rate of } \\
\text { Available } \\
\text { Vols. } \\
\end{array}$ \\
\hline 39 & 4.3 & $\begin{array}{l}\text { Materials of } \\
\text { Engineering }\end{array}$ & Polymers & TA455 .P58 & 86 & 5 & 17.2 & 6 & $83 \%$ \\
\hline 40 & 4.3 & Computers & Quantum Computers & QA76.889 & 85 & 5 & 17.0 & 10 & $50 \%$ \\
\hline 41 & 4.2 & Electronics & Microelectronics & TK7874 & 70 & 6 & 11.7 & 8 & $75 \%$ \\
\hline 42 & 4.1 & Computers & Client/Server Computing & QA76.9.C55 & 82 & 5 & 16.4 & 6 & $83 \%$ \\
\hline 43 & 4.1 & $\begin{array}{l}\text { Materials of } \\
\text { Engineering }\end{array}$ & Carbon & TA455.C3 & 58 & 7 & 8.3 & 8 & $88 \%$ \\
\hline 44 & 4.1 & Probabilities & Probabilities, General & QA273 & 81 & 5 & 16.2 & 12 & $42 \%$ \\
\hline 45 & 3.9 & Machinery & Tribology. Lubrication and Friction & TJ1075 & 78 & 5 & 15.6 & 5 & $100 \%$ \\
\hline 46 & 3.8 & Science Research & Research, Special Topics & Q180.55 & 63 & 6 & 10.5 & 15 & $40 \%$ \\
\hline 47 & 3.8 & Organic Chemistry & Polymers, Special Types & QD382 & 63 & 6 & 10.5 & 6 & $100 \%$ \\
\hline 48 & 3.8 & $\begin{array}{l}\text { Physical and } \\
\text { Theoretical Chemistry }\end{array}$ & $\begin{array}{l}\text { Atomic and Molecular Theory and } \\
\text { Structure }\end{array}$ & QD461 & 63 & 6 & 10.5 & 8 & $75 \%$ \\
\hline 49 & 3.7 & $\begin{array}{l}\text { Computers and } \\
\text { Special Computing }\end{array}$ & Database Design & QA76.9 .D26 & 92 & 4 & 23.0 & 4 & $100 \%$ \\
\hline 50 & 3.5 & Programming & Visual Basic & QA76.73.B3 & 116 & 3 & 38.7 & 3 & $100 \%$ \\
\hline
\end{tabular}


Table 5. Top Call Numbers Arranged by Call Number

\begin{tabular}{|c|c|c|c|}
\hline Call Number $^{\mathrm{a}}$ & Rank $^{b}$ & Subject Area & Specific Topic \\
\hline$\underline{Q 180.55}$ & $46 n$ & Science Research & $\begin{array}{l}\text { Special Topics in Research (Methodology, Statistical Methods, } \\
\text { Proposal Writing, etc.) }\end{array}$ \\
\hline Q335 & $68 \mathrm{a}$ & Cybernetics & Artificial Intelligence \\
\hline QA76.73 & $13 a, 17 n$ & Programming & Programming Languages (Fortran, Basic, SQL, etc.) \\
\hline$\overline{\overline{\text { QA76.73 .B3 }}}$ & $50 n$ & Programming & Visual Basic \\
\hline QA76.73.C15x & $5 a, 36 n$ & Programming & C Programming Languages (C, $\mathrm{C}++, \mathrm{C \#})$ \\
\hline QA76.73 .J38 & $26 a, 2 n$ & Programming & Java Language \\
\hline QA76.76 & $38 a, 8 n$ & Software & Software Topics (Development, Software Testing, Windows, etc.) \\
\hline$\overline{\text { QA76.76 .E95 }}$ & $95 a$ & Software & Expert Systems \\
\hline QA76.76.H94 & $76 a, 3 n$ & Software & Hypertext Systems (Includes HTML \& XML) \\
\hline QA76.76.063 & $35 a, 1 n$ & Software & Operating Systems (Windows, Linux, Unix) \\
\hline QA76.87 & $61 \mathrm{a}$ & Computers and Special Computing & Neural Computers \& Networks \\
\hline QA76.889 & $40 n$ & Computers and Special Computing & Quantum Computers \\
\hline QA76.9 & $3 a, 10 n$ & Computers and Special Computing & $\begin{array}{l}\text { Computer Topics (Security/Access Control, Client/Server, Simulation, } \\
\text { Natural Language, etc.) }\end{array}$ \\
\hline QA76.9.C55 & $42 n$ & Computers and Special Computing & Client/Server Computing \\
\hline QA76.9.D26 & $49 n$ & Computers and Special Computing & Database Design \\
\hline QA76.9.D3 & $77 \mathrm{a}, 11 \mathrm{n}$ & Computers and Special Computing & Database Management \\
\hline QA76.9.035 & $35 n$ & Computers and Special Computing & Object-Oriented Methods \\
\hline QA171 & $55 a$ & Algebra & Group Theory \\
\hline QA273 & $7 a, 44 n$ & Probabilities & Probabilities, General \\
\hline QA273.6 & $42 a$ & Probabilities & Distributions. \\
\hline QA274.2 - QA274.28 & $93 a$ & Probabilities & Stochastic Analysis \\
\hline QA274.7x & $39 a$ & Probabilities & Markov Processes \& Chains \\
\hline QA276 & $6 a$ & Mathematical Statistics & Mathematical Statistics, General \\
\hline QA278 & $30 a$ & Mathematical Statistics & Multivariate Analysis \\
\hline QA278.2 & $27 a$ & Mathematical Statistics & Regression \& Correlations Analysis \\
\hline
\end{tabular}

\footnotetext{
a Underlined Call Numbers represent numbers that further subdivide into subtopics. Sample subtopics are listed in parentheses following Specific Topic.

${ }^{b}$ In the column Rank, the numbers followed by "a" represent the ranking in Table 3 for All Books, and numbers followed by " $n$ " represent the ranking in Table 4 for New Books Table 5
} 


\begin{tabular}{|c|c|c|c|}
\hline Call Number & Rank & Subject Area & Specific Topic \\
\hline QA279 & $24 a, 25 n$ & Mathematical Statistics & Nonparametric Methods \\
\hline QA279.5 & $13 n$ & Mathematical Statistics & Bayesian Statistics \\
\hline QA280 & $62 a$ & Mathematical Statistics & Time Series Analysis \\
\hline QA297 & $25 a$ & Mathematical Analysis & Numerical Analysis \\
\hline QA371 & $75 a$ & Mathematical Analysis & Differential Equations \\
\hline QA377 & $89 a$ & Mathematical Analysis & Partial Differential Equations \\
\hline QA402.3x & $45 a$ & Mathematical Analysis & Control Theory \\
\hline QA402.5 & $47 a$ & Mathematical Analysis & Mathematical Optimization. Programming \\
\hline QA611 & $70 a$ & Geometry & Topology \\
\hline QA911 & $60 a$ & Analytic Mechanics & Fluid Dynamics. Hydraulics \\
\hline QA931 & $46 a$ & Analytic Mechanics & Elasticity. Plasticity \\
\hline$\underline{Q} 220.7$ & $17 a$ & Mathematical Physics & $\begin{array}{l}\text { Mathematical Physics, Special (Density Functionals, Differential } \\
\text { Geometry, Spinor Analysis, Group Theory, etc.) }\end{array}$ \\
\hline QC173 & $73 a$ & Atomic Physics & Matter and Antimatter, General \\
\hline QC173.4 & $29 a, 20 n$ & Atomic Physics & $\begin{array}{l}\text { Matter and Antimatter, Special (Condensed Matter, Polymers, Critical } \\
\text { Phenomena, etc.) }\end{array}$ \\
\hline QC173.4.S94 & $99 a$ & Atomic Physics & Surfaces \\
\hline QC174.12 & $21 a, 7 n$ & Atomic Physics & Quantum Theory \& Mechanics, General \\
\hline QC174.17 & $37 a$ & Atomic Physics & $\begin{array}{l}\text { Quantum Theory \& Mechanics, Special (Chaos, Mathematical } \\
\text { Logic, Path Integrals, Many-Body Problem, etc.) }\end{array}$ \\
\hline QC174.45 & $58 a$ & Atomic Physics & Quantum Field Theory \\
\hline QC174.8 & $28 a$ & Atomic Physics & Statistical Physics, General \\
\hline QC174.85 & $78 a, 26 n$ & Atomic Physics & Statistical Physics, Special (Monte Carlo Method, Percolation, etc.) \\
\hline QC176 & $16 a$ & Atomic Physics & Solids, Solid State Physics. General \\
\hline$\underline{Q}$ Q176.8 & $6 n$ & Atomic Physics & $\begin{array}{l}\text { Solids, Solid State Physics. Special (Optical Properties, Radiation } \\
\text { Effects, Nanostructures, etc.) }\end{array}$ \\
\hline QC311 & $53 a$ & Heat & Thermodynamics \\
\hline QC320 & $43 a$ & Heat & Heat Transfer \\
\hline
\end{tabular}




\begin{tabular}{|c|c|c|c|}
\hline Call Number & Rank & Subject Area & Specific Topic \\
\hline QC355 - QC355.2 & $32 a, 32 n$ & Optics. Light & Optics, General \\
\hline QC446.2 & $56 a, 22 n$ & Optics. Light & Nonlinear \& Quantum Optics \\
\hline QC454 & $2 a, 23 n$ & Optics. Light & Spectroscopy, Special (Atomic, Electron, Laser, Molecular, etc.) \\
\hline QC482 & $63 a$ & Radiation Physics & X-Rays \& Roentgen Rays (Diffraction, Spectroscopy, Scattering, etc.) \\
\hline QC611 & $88 a$ & Electricity & Semiconductor Physics, General \\
\hline QC612 & $97 a$ & Electricity & Superconductivity Physics, Special \\
\hline QC612.S4 & $82 a$ & Electricity & Semiconductors \\
\hline QC670 & $86 a$ & Electricity & Electromagnetic Theory \\
\hline QC753 - QC753.2 & $80 a$ & Magnetism & Magnetism, General \\
\hline QC793.3 & $98 a$ & Nuclear Physics & $\begin{array}{l}\text { Elementary Particle Physics (Angular Momentum, Field Theories, } \\
\text { Structure, etc.) }\end{array}$ \\
\hline$\underline{Q C 793.5}$ & $8 a$ & Nuclear Physics & $\begin{array}{l}\text { Special Particles, Antiparticles, Families of Particles (Electrons, } \\
\text { Neutrons, Photons, etc.) }\end{array}$ \\
\hline QD39.3 & $84 a$ & Chemistry & $\begin{array}{l}\text { Chemistry, Special Topics (Mathematics, Statistical Methods, Factor } \\
\text { Analysis, Cheminformatics, etc.) }\end{array}$ \\
\hline QD75.4 & $67 a$ & Analytical Chemistry & $\begin{array}{l}\text { Analytical Chemistry, Special (Quality Control, Statistical Methods, } \\
\text { Electronic Data Processing, etc.) }\end{array}$ \\
\hline$\underline{\text { QD79 }}$ & $38 n$ & Analytical Chemistry & Methods of Analysis (Instrumental Analysis, Thermal Analysis) \\
\hline QD79.Cx & $31 \mathrm{a}$ & Analytical Chemistry & Chromatographic Analysis \\
\hline$\underline{\text { QD96 }}$ & $1 a, 9 n$ & Analytical Chemistry & $\begin{array}{l}\text { Spectrum Analysis, Special Types of Spectroscopy } \\
\text { (Spectroscopy: Fluorescence, Fourier Transform, Infrared, Mass, Nuclear } \\
\text { Magnetic Resonance) }\end{array}$ \\
\hline QD181 & $10 a$ & Inorganic Chemistry & Special Inorganic Elements (Carbon, Oxides, Silicon, etc.) \\
\hline QD281.P6 & $90 a$ & Organic Chemistry & Polymerization. Telomerization. \\
\hline QD381 & $12 a$ & Organic Chemistry & Polymers. Macromolecules, General \\
\hline QD382 & $47 n$ & Organic Chemistry & $\begin{array}{l}\text { Polymers. Macromolecules, Special Types (Conductors, } \\
\text { Crystalline, Water-Soluble, etc.) }\end{array}$ \\
\hline QD453 - QD453.2 & $83 a, 28 n$ & Physical and Theoretical Chemistry & Physical and Theoretical Chemistry, General \\
\hline QD461 & $16 a, 48 n$ & Physical and Theoretical Chemistry & Atomic and Molecular Theory and Structure \\
\hline
\end{tabular}

Table 5 


\begin{tabular}{|c|c|c|c|}
\hline Call Number & Rank & Subject Area & Specific Topic \\
\hline QD462 & $91 \mathrm{a}, 27 \mathrm{n}$ & Physical and Theoretical Chemistry & Quantum Chemistry \\
\hline QD501 & $66 a$ & Physical and Theoretical Chemistry & Chemical Reactions \\
\hline QD506 & $57 a$ & Physical and Theoretical Chemistry & Surface Chemistry \\
\hline QD921 & $54 a$ & Crystallography & Crystal Structure and Growth \\
\hline QD945 & $74 a$ & Crystallography & X-Ray Crystallography \\
\hline QP519.9 & $14 a$ & Biochemistry & $\begin{array}{l}\text { Biochemistry Technique. Analytical Biochemistry, Special } \\
\text { (Affinity Chromatography, Mass Spectrometry, Spectroscopy, Nuclear } \\
\text { Magnetic Resonance Spectroscopy, etc.) }\end{array}$ \\
\hline QP551 & $19 a, 37 n$ & Biochemistry & Proteins \\
\hline$\underline{\mathrm{R} 857}$ & $15 a, 19 n$ & Biomedical Engineering & $\begin{array}{l}\text { Biomedical Engineering (Biosensors, Biomedical Materials, Polymers } \\
\text { etc.) }\end{array}$ \\
\hline R857 .M3 & $33 n$ & Biomedical Engineering & Biomedical Materials \\
\hline T174.7 & $12 n$ & Technology, General & Nanotechnology \\
\hline T385 & $49 a, 31 n$ & Mechanical Drawing & Computer Graphics \\
\hline TA345 & $96 a, 14 n$ & Engineering Mathematics & Computer-Aided Engineering. Data Processing. \\
\hline TA347.F5 & $85 a$ & Engineering Mathematics & Finite Element Method of Problem Solving \\
\hline TA357 & $64 a$ & Mechanics of Engineering & Applied Fluid Mechanics \\
\hline TA409 & $87 a$ & Materials of Engineering & Failure of Materials. \\
\hline TA418.7 & $71 \mathrm{a}$ & Materials of Engineering & Surface Effects and Tests \\
\hline TA418.9 & $24 n$ & Materials of Engineering & $\begin{array}{l}\text { Materials of Special Composition (Nanostructure Materials, } \\
\text { Composite Materials, Smart Materials, etc.) }\end{array}$ \\
\hline TA418.9.C6 & $51 \mathrm{a}$ & Materials of Engineering & Composite Materials \\
\hline TA418.9 .N35 & $5 n$ & Materials of Engineering & Nanostructure Materials \\
\hline$\underline{\text { TA455 }}$ & $69 a$ & Materials of Engineering & Nonmetallic Materials (Carbon, Ceramics, Plastics, etc.) \\
\hline TA1632 & $36 a$ & Applied Optics & Optical Data Processing \\
\hline TA1637 & $48 a, 21 n$ & Applied Optics & Image Processing \\
\hline
\end{tabular}




\begin{tabular}{|c|c|c|c|}
\hline Call Number & Rank & Subject Area & Specific Topic \\
\hline TJ211 & $34 a$ & Robotics and Automatic Machinery & Mechanical Devices. Automata. Robots, General \\
\hline TJ213 & $52 a$ & Robotics and Automatic Machinery & Control Engineering Systems \\
\hline TJ1075 & $72 a, 45 n$ & Machinery & Tribology. Lubrication and Friction \\
\hline TK5102.5 & $44 a$ & Telecommunication & Telecommunication, Special (Digital Signal Processing, etc.) \\
\hline TK5102.9 & $16 n$ & Telecommunication & Signal Processing \\
\hline TK5103.59 & $79 a$ & Telecommunication & Optical Communications \\
\hline TK5105.5 & $92 a$ & Telecommunication & Computer Networks, General \\
\hline TK5105.585 & $29 n$ & Telecommunication & TCP/IP \\
\hline TK5105.888 & $81 a, 4 n$ & Telecommunication & World Wide Web \\
\hline TK5105.8885 .A26 & $30 n$ & Telecommunication & Active Server Pages \\
\hline TK7871.15 & $50 a$ & Electronics & Materials, Special (Ceramic Materials, Gallium, Silicon, Films, etc.) \\
\hline$\overline{\text { TK7871.85 }}$ & $11 a, 15 n$ & Electronics & Semiconductors \\
\hline TK7872 & $41 \mathrm{a}$ & Electronics & Apparatus and Materials \\
\hline TK7874 & $22 a, 41 n$ & Electronics & Microelectronics \\
\hline TK7875 & $18 n$ & Electronics & Microelectromechanical Systems \\
\hline TN690 & $33 a$ & Metallography & Metallography, General \\
\hline TP156 & $23 a$ & Chemical Engineering & $\begin{array}{l}\text { Special Processes \& Operations (Coating, Emulsion, Mixing, } \\
\text { Polymerization, etc.) }\end{array}$ \\
\hline
\end{tabular}


Table 6. Top 30 Most Circulated Titles for All Books

\begin{tabular}{|c|c|c|c|c|}
\hline Rank & $\begin{array}{l}\text { Trans- } \\
\text { actions }\end{array}$ & Title & Call Number $^{\mathrm{a}}$ & Subject Area -- Specific Topic ${ }^{b}$ \\
\hline 1 & 157 & $\begin{array}{l}\text { The Waite Group's C++ programming / } \\
\text { John Thomas Berry. }\end{array}$ & $\begin{array}{l}\text { QA76.73 .C15 B47 } \\
\text { 1992 }\end{array}$ & Programming -- C/C++ Language \\
\hline 2 & 155 & $\begin{array}{l}\text { Applied regression analysis / N.R. Draper, } \\
\text { H. Smith. }\end{array}$ & QA278.2 .D7 1981 & $\begin{array}{l}\text { Mathematical Statistics -- Regression \& Correlations } \\
\text { Analysis }\end{array}$ \\
\hline 3 & 143 & \begin{tabular}{|l|} 
Probability and measure / Patrick \\
Billingsley.
\end{tabular} & QA273 .B575 1979 & Probabilities -- Probabilities, General \\
\hline 4 & 140 & $\begin{array}{l}\text { The C programming language / Brian W. } \\
\text { Kernighan, Dennis M. Ritchie. }\end{array}$ & $\begin{array}{l}\text { QA76.73 .C15 K47 } \\
1988\end{array}$ & Programming -- C/C++ Language \\
\hline 5 & 138 & $\begin{array}{l}\text { Numerical recipes : the art of scientific } \\
\text { computing / William H. Press ... [et al.]. }\end{array}$ & QA297 .N866 1986 & Mathematical Analysis -- Numerical Analysis \\
\hline 6 & 135 & $\begin{array}{l}\text { Diffusion and heat transfer in chemical } \\
\text { kinetics [by] David A. Frank-Kamenetskii. } \\
\text { Translation editor: John P. Appleton. }\end{array}$ & QD543 .F6413 1969 & $\begin{array}{l}\text { Physical and Theoretical Chemistry -- Solubility, Diffusion, } \\
\text { etc. }\end{array}$ \\
\hline 7 & 130 & $\begin{array}{l}\text { Magnetochemistry / by Pierce W. } \\
\text { Selwood. }\end{array}$ & QD591.S45 1956 & Physical and Theoretical Chemistry -- Magnetochemistry \\
\hline 8 & 121 & $\begin{array}{l}\text { The C book, featuring the draft ANSI C } \\
\text { standard / Mike Banahan. }\end{array}$ & $\begin{array}{l}\text { QA76.73 .C15 B36 } \\
\text { 1988 }\end{array}$ & Programming -- C/C++ Language \\
\hline 9 & 120 & Rheological techniques / R. W. Whorlow. & QC189.5 .W48 1980 & Atomic Physics -- Rheology \\
\hline 10 & 119 & $\begin{array}{l}\text { C, a reference manual / Samuel P. } \\
\text { Harbison, Guy L. Steele, Jr. }\end{array}$ & $\begin{array}{l}\text { QA76.73 .C15 H38 } \\
1991\end{array}$ & Programming -- $\mathrm{C} / \mathrm{C}++$ Language \\
\hline 11 & 117 & $\begin{array}{l}\text { The fast Fourier transform [by] E. Oran } \\
\text { Brigham. }\end{array}$ & QA403 .B74 1974 & Mathematical Analysis -- Harmonic Analysis \\
\hline 12 & 116 & $\begin{array}{l}\text { Elsevier's dictionary of science and } \\
\text { technology. Russian-English / compiled } \\
\text { by G. Chakalov. }\end{array}$ & Q123.C4817 1993 & Science --Dictionaries \\
\hline 13 & 116 & $\begin{array}{l}\text { Ion bombardment modification of surfaces } \\
\text { : fundamentals and applications / edited } \\
\text { by Orlando Auciello, Roger Kelly. }\end{array}$ & TA418.7 .165 1984 & Materials of Engineering -- Surface Effects and Tests \\
\hline 14 & 115 & $\begin{array}{l}\text { Mathematical methods for physicists / } \\
\text { George Arfken. }\end{array}$ & QA37.2 .A74 1970 & Mathematics--Textbooks \\
\hline 15 & 115 & Neutron diffraction / by G. E. Bacon. & $\begin{array}{l}\text { QC793.5 .N4628 B3 } \\
1975\end{array}$ & $\begin{array}{l}\text { Nuclear Physics -- Special Particles, Antiparticles, Families } \\
\text { of Particles }\end{array}$ \\
\hline 16 & 111 & pH measurements / C. Clark Westcott. & QD561.W52 1978 & $\begin{array}{l}\text { Physical and Theoretical Chemistry -- Electrochemistry, lons } \\
\text { and lonization }\end{array}$ \\
\hline 17 & 110 & $\begin{array}{l}\text { Polymers and neutron scattering / Julia S. } \\
\text { Higgins and Henri C. Benoit. }\end{array}$ & $\begin{array}{l}\text { QC173.4 .P65 H54 } \\
1994\end{array}$ & Atomic Physics -- Polymers, Properties \\
\hline
\end{tabular}

\footnotetext{
${ }^{a}$ Call numbers shown in bold are those that appeared on the list of Top Call Numbers in Table 5.

${ }^{\mathrm{b}}$ Subject Divisions and Specific Topics shown in bold are those that appeared on the list of Top Call Numbers in Table 5. Table 6
} 


\begin{tabular}{|c|c|c|c|c|}
\hline Rank & $\begin{array}{l}\text { Trans- } \\
\text { actions }\end{array}$ & Title & Call Number & Subject Area - Specific Topic \\
\hline 18 & 109 & $\begin{array}{l}\text { Programmer's guide to Fortran } 90 \text { / } \\
\text { Walter S. Brainerd, Charles H. Goldberg, } \\
\text { Jeanne C. Adams. }\end{array}$ & $\begin{array}{l}\text { QA76.73 .F25 B72 } \\
1990\end{array}$ & Programming -- Fortran \\
\hline 19 & 109 & $\begin{array}{l}\text { Glow discharge processes : sputtering } \\
\text { and plasma etching / Brian Chapman. }\end{array}$ & $\begin{array}{l}\text { QC702.7 .P6 C48 } \\
1980 \text { C.2 } \\
\end{array}$ & Electricity -- Positive lons \\
\hline 20 & 108 & $\begin{array}{l}\text { Introduction to matrix computations [by] } \\
\text { G. W. Stewart. }\end{array}$ & QA188 .S7 1973 & Algebra -- Matrices \\
\hline 21 & 107 & $\begin{array}{l}\text { The theory of atomic structure and } \\
\text { spectra / Robert D. Cowan. }\end{array}$ & QC173.C693 1981 & Atomic Physics -- Matter and Antimatter, General \\
\hline 22 & 107 & $\begin{array}{l}\text { Handbook of optics / sponsored by the } \\
\text { Optical Society of America ; Walter G. } \\
\text { Driscoll, editor, William Vaughan, } \\
\text { associate editor. }\end{array}$ & QC369.H35 1978 & Optics. Light -- Handbooks \\
\hline 23 & 105 & $\begin{array}{l}\text { Viscosity of polymer solutions / Miloslav } \\
\text { Bohdanecky and Josef Kovar. }\end{array}$ & QD381.8 .B63 1982 & Organic Chemistry -- Polymers \\
\hline 24 & 105 & $\begin{array}{l}\text { Secondary ion mass spectrometry : basic } \\
\text { concepts, instrumental aspects, } \\
\text { applications, and trends / A. } \\
\text { Benninghoven, F.G. Rudenauer, H.W. } \\
\text { Werner. }\end{array}$ & QD96 .S43 B46 1987 & Analytical Chemistry -- Spectrum Analysis, Special \\
\hline 25 & 105 & $\begin{array}{l}\text { Particle size measurement / Terence } \\
\text { Allen. }\end{array}$ & TA418.8 .A43 1990 & Materials of Engineering -- Particle Size Determination \\
\hline 26 & 104 & $\begin{array}{l}\text { The C programming language / Brian W. } \\
\text { Kernighan, Dennis M. Ritchie. }\end{array}$ & $\begin{array}{l}\text { QA76.73 .C15 K47 } \\
1988\end{array}$ & Programming -- C/C++ Language \\
\hline 27 & 104 & $\begin{array}{l}\text { Transport phenomena / R. Byron Bird, } \\
\text { Warren E. Stewart, Edwin N. Lightfoot. }\end{array}$ & QA929 .B5 1960 & Analytic Mechanics -- Fluid Dynamics Viscous Fluids \\
\hline 28 & 104 & $\begin{array}{l}\text { Fundamentals of heat transfer / Frank P. } \\
\text { Incropera, David P. DeWitt. }\end{array}$ & QC320.145 1981 & Heat -- Heat Transfer \\
\hline 29 & 104 & $\begin{array}{l}\text { An introduction to crystal chemistry / by } \\
\text { R.C. Evans. }\end{array}$ & QD905 .E83 1964 & Crystallography -- General Works \\
\hline 30 & 104 & $\begin{array}{l}\text { The properties of gases and liquids / } \\
\text { Robert C. Reid, John M. Prausnitz, } \\
\text { Thomas K. Sherwood. }\end{array}$ & TP242 .R4 1977 & Chemicals -- Gases \\
\hline
\end{tabular}


Table 7. Top 30 Most Circulated Titles for New Books (1999-2004)

\begin{tabular}{|c|c|c|c|c|}
\hline Rank & $\begin{array}{l}\text { Trans- } \\
\text { actions }\end{array}$ & Title & Call Number ${ }^{a}$ & Subject Area - Specific Topic ${ }^{b}$ \\
\hline 1 & 65 & $\begin{array}{l}\text { Beginning Visual basic SQL server } 7.0 \text { / } \\
\text { Thearon Willis. }\end{array}$ & $\begin{array}{l}\text { QA76.9 .C55 W53 } \\
2000\end{array}$ & $\begin{array}{l}\text { Computer Systems and Spc. Computing -- Client/Server } \\
\text { Computing }\end{array}$ \\
\hline 2 & 62 & $\begin{array}{l}\text { UML distilled : a brief guide to the standard } \\
\text { object modeling language / Martin Fowler } \\
\text { with Kendall Scott ; [foreword by Grady } \\
\text { Booch, Ivar Jacobson, and James } \\
\text { Rumbaugh]. }\end{array}$ & $\begin{array}{l}\text { QA76.9 .035 F694 } \\
2000\end{array}$ & $\begin{array}{l}\text { Computer Systems and Spc. Computing -- Object-Oriented } \\
\text { Methods }\end{array}$ \\
\hline 3 & 60 & $\begin{array}{l}\text { Programming Microsoft Visual Basic } 6.0 \text { / } \\
\text { Francesco Balena; [foreword by James } \\
\text { Fawcette]. }\end{array}$ & $\begin{array}{l}\text { QA76.73 .B3 B345 } \\
1999\end{array}$ & Programming -- Visual Basic \\
\hline 4 & 57 & $\begin{array}{l}\text { Introduction to superstrings and M-theory / } \\
\text { Michio Kaku. }\end{array}$ & $\begin{array}{l}\text { QC794.6 .S85 K35 } \\
1999\end{array}$ & Nuclear Physics -- String Models \\
\hline 5 & 55 & $\begin{array}{l}\text { Object-oriented software development in } \\
\text { Java: principles, patterns, and frameworks / } \\
\text { Xiaoping Jia. }\end{array}$ & QA76.64 .J53 2000 & Programming -- Object-Oriented Programming \\
\hline 6 & 54 & Organic chemistry. & QD253 .S65 2000 & Organic Chemistry -- Textbooks \\
\hline 7 & 53 & $\begin{array}{l}\text { Introduction to surface and thin film } \\
\text { processes / John A. Venables. }\end{array}$ & QC176.83.V46 2000 & Atomic Physics - Thin Films \\
\hline 8 & 52 & $\begin{array}{l}\text { Free boundary problems : theory and } \\
\text { applications / I. Athanasopoulos, G. } \\
\text { Makrakis, J.F. Rodrigues, editors. }\end{array}$ & $\begin{array}{l}\text { TA347 .B69 F743 } \\
1999\end{array}$ & Engineering Mathematics - Boundary Value Problems \\
\hline 9 & 50 & $\begin{array}{l}\text { Mastering database programming with } \\
\text { Visual Basic } 6 \text { / Evangelos Petroutsos. }\end{array}$ & $\begin{array}{l}\text { QA76.73 .B3 P49 } \\
2000\end{array}$ & Programming -- Visual Basic \\
\hline 10 & 50 & $\begin{array}{l}\text { Joe Celko's SQL for smarties : advanced } \\
\text { SQL programming / Joe Celko. }\end{array}$ & $\begin{array}{l}\text { QA76.73 .S67 C44 } \\
2000\end{array}$ & Programming -- SQL Programming \\
\hline 11 & 49 & $\begin{array}{l}\text { LabVIEW applications and solutions / } \\
\text { Rahman Jamal, Herbert Pichlik. }\end{array}$ & Q185 .J36 1999 & Science Instruments and Apparatus -- General Works \\
\hline 12 & 49 & $\begin{array}{l}\text { XML and Java: developing Web } \\
\text { applications / Hiroshi Maruyama, Kent } \\
\text { Tamura, Naohiko Uramoto. }\end{array}$ & $\begin{array}{l}\text { QA76.76 .H94 M28 } \\
1999\end{array}$ & Software -- Hypertext Systems \\
\hline 13 & 49 & $\begin{array}{l}\text { Colossal magnetoresistive oxides / edited } \\
\text { by Yoshinori Tokura. }\end{array}$ & QC610.7.C653 2000 & Electricity -- Magnetoresistance \\
\hline 14 & 48 & $\begin{array}{l}\text { Java look and feel design guidelines / Sun } \\
\text { Microsystems, Inc. }\end{array}$ & $\begin{array}{l}\text { QA76.73 .J38 J373 } \\
2001\end{array}$ & Programming -- Java Language \\
\hline 15 & 46 & $\begin{array}{l}\text { Radiation detection and measurement / } \\
\text { Glenn F. Knoll. }\end{array}$ & QC787.C6 K56 2000 & Nuclear Physics -- Counters (Instrument) \\
\hline
\end{tabular}

\footnotetext{
${ }^{a}$ Call numbers shown in bold are those that appeared on the list of Top Call Numbers in Table 5.

${ }^{b}$ Subject Divisions and Specific Topics shown in bold are those that appeared on the list of Top Call Numbers in Table 5 . Table 7
} 


\begin{tabular}{|c|c|c|c|c|}
\hline Rank & $\begin{array}{l}\text { Trans- } \\
\text { actions }\end{array}$ & Title & Call Number & Subject Area - Specific Topic \\
\hline 16 & 46 & $\begin{array}{l}\text { Introduction to high energy physics / } \\
\text { Donald H. Perkins. }\end{array}$ & QC793.2 .P47 2000 & Nuclear Physics -- Elementary Particle Physics \\
\hline 17 & 46 & $\begin{array}{l}\text { Handbook of property estimation methods } \\
\text { for environmental chemicals: } \\
\text { environmental and health sciences / } \\
\text { [edited by] Robert S. Boethling, Donald } \\
\text { Mackay. }\end{array}$ & QD271.H3186 2000 & Organic Chemistry -- Organic Analysis \\
\hline 18 & 46 & $\begin{array}{l}\text { Circular dichroism : principles and } \\
\text { applications / edited by Nina Berova, Koji } \\
\text { Nakanishi, Robert W. Woody. }\end{array}$ & QD473 .C57 2000 & $\begin{array}{l}\text { Physical and Theoretical Chemistry -- Physical Properties in } \\
\text { Relation to Structure }\end{array}$ \\
\hline 19 & 46 & $\begin{array}{l}\text { Handbook of biomaterials evaluation: } \\
\text { scientific, technical, and clinical testing of } \\
\text { implant materials / editor, Andreas F. von } \\
\text { Recum. }\end{array}$ & R857 .M3 H35 1999 & Biomedical Engineering -- Biomedical Materials \\
\hline 20 & & $\begin{array}{l}\text { Guide to Linux installation and } \\
\text { administration / Nicholas Wells with } \\
\text { Michael Jang. }\end{array}$ & $\begin{array}{l}\text { QA76.76 .063 W45 } \\
2000\end{array}$ & Software -- Operating Systems (Windows, Linux, Unix) \\
\hline 21 & 45 & $\begin{array}{l}\text { Chemical-mechanical polishing-- } \\
\text { fundmentals and materials issues : } \\
\text { symposium held ... }\end{array}$ & TS654.5 .C48 2000 & Metal Manufactures -- Electrolytic Polishing \\
\hline 22 & 44 & $\begin{array}{l}\text { Designing flexible object-oriented systems } \\
\text { with UML / Charles Richter. }\end{array}$ & QA76.64 .R535 1999 & Programming -- Object-oriented programming \\
\hline 23 & 44 & $\begin{array}{l}\text { Java programming : advanced topics / Joe } \\
\text { Wigglesworth and Paula Lumby. }\end{array}$ & $\begin{array}{l}\text { QA76.73 .J38 W54 } \\
2000\end{array}$ & Programming -- Java Language \\
\hline 24 & & $\begin{array}{l}\text { Principles of optics : electromagnetic } \\
\text { theory of propagation, interference and } \\
\text { diffraction of light / Max Born and Emil } \\
\text { Wolf ; with contributions by A.B. Bhatia ... } \\
\text { [et al.]. }\end{array}$ & QC355.2 .B67 1999 & Optics. Light -- Optics, General \\
\hline 25 & 44 & $\begin{array}{l}\text { Quantum chemistry : fundamentals to } \\
\text { applications / Tams Veszpremi and Miklos } \\
\text { Feher. }\end{array}$ & QD462 .V48 1999 & Physical and Theoretical Chemistry -- Quantum Chemistry \\
\hline 26 & 44 & $\begin{array}{l}\text { Principles and techniques of practical } \\
\text { biochemistry / edited by Keith Wilson and } \\
\text { John Walker. }\end{array}$ & QP519.7 .P75 2000 & $\begin{array}{l}\text { Biochemistry -- Biochemistry Technique. Analytical } \\
\text { Biochemistry, Gen. }\end{array}$ \\
\hline 27 & 43 & $\begin{array}{l}\text { Condensed matter physics / Michael P. } \\
\text { Marder. }\end{array}$ & $\begin{array}{l}\text { QC173.454 .M37 } \\
2000\end{array}$ & Atomic Physics -- Condensed Matter Physics \\
\hline 28 & 43 & $\begin{array}{l}\text { Time-frequency/time scale analysis / } \\
\text { Patrick Flandrin; translated from the } \\
\text { French by Joachim Stockler. }\end{array}$ & $\begin{array}{l}\text { TK5102.9 .F5513 } \\
1999\end{array}$ & Telecommunication -- Signal Processing \\
\hline
\end{tabular}




\begin{tabular}{|r|r|l|l|l|}
\hline Rank & $\begin{array}{l}\text { Trans- } \\
\text { actions }\end{array}$ & \multicolumn{1}{|c|}{ Title } & Call Number & \multicolumn{1}{|c|}{ Subject Area - Specific Topic } \\
\hline 29 & 42 & $\begin{array}{l}\text { The pragmatic programmer : from } \\
\text { journeyman to master / Andrew Hunt, } \\
\text { David Thomas; [foreword by Ward } \\
\text { Cunningham]. }\end{array}$ & QA76.6 .H857 2000 & Programming -- Programming, General \\
\hline 30 & $42 \begin{array}{l}\text { Rapid application development with Visual } \\
\text { Basic 6 / David McMahon. }\end{array}$ & $\begin{array}{l}\text { QA76.76 .A65 M425 } \\
2000\end{array}$ & Software -- Application Software \\
\hline
\end{tabular}

